\title{
Institutional Investment Horizons and CEO Compensation*
}

\author{
JAE YONG SHIN ${ }^{* *}$ \\ Seoul National University \\ Seoul, Korea
}

\begin{abstract}
I investigate the relation between the structure of CEO compensation and the investment horizons of a firm's institutional investors and find results consistent with the assertion that short-sighted institutions' focus on shortterm earnings leads firms to grant more options with higher sensitivity to stock price. In contrast, the percentage holdings of long-term investors are negatively correlated with the use of options and the sensitivity of total CEO equity incentives to changes in stock price. Further results suggest that firms with higher short-term institutional ownership are more concerned about a negative earnings surprise and that when determining annual bonuses, they punish their CEOs more severely. In total, the analyses provide evidence that the investment horizon of institutional investors is associated with firms' CEO compensation policies.
\end{abstract}

* I thank Christine Botosan, Mary Ellen Carter, John Core, William Cready, Fabrizio Ferri, Rachel Hayes, Lee-Seok Hwang, Li Jin, Ella Mae Matsumura, Martin Wu, and workshop participants at the University of Illinois at UrbanaChampaign, at the University of Utah, at the University of Wisconsin-Madison, at Korea University, at Seoul National University, and at the Korea Advanced Institute of Science and Technology (KAIST) for many helpful comments. Many helpful comments were also received from conference participants at the $4^{\text {th }}$ Asian Corporate Governance Conference in Seoul, South Korea, at the American Accounting Association Annual Meeting, at the Mid-year Meeting of the American Accounting Association's Management-Accounting Section, and at the $16^{\text {th }}$ Annual Conference on Financial Economics and Accounting (FEA) at the University of North Carolina at Chapel Hill. I gratefully acknowledge financial support from the Institute of Management Research at Seoul National University. This work was also supported by Research Settlement Fund for the new faculty of SNU.

** Assistant Professor, College of Business Administration, Seoul National University, 599 Gwanangno, Gwanak-gu, Seoul, Korea, 151-916 (jshin@snu.ac.kr), Phone: +85-2-880-6940 
Keywords: Ownership; Institutional investors; Investment horizons; CEO compensation

\section{INTRODUCTION}

The purpose of this paper is to examine whether the investment horizons of a firm's institutional investors are associated with the structure of CEO compensation. Empirical and anecdotal evidence suggests that some U.S. institutional investors have become active in monitoring corporate governance (Del Guercio and Hawkins 1999; Gillan and Starks 2000, 2003; Holmstrom and Kaplan 2001). One important factor that concerns firms' corporate governance and that institutional investors can actively monitor is the process of evaluating and rewarding managerial performance (e.g., Hartzell and Starks 2003).

In this paper, I argue that the investment horizon of institutional investors can influence executive compensation in both direct ways and indirect ways. Direct monitoring is likely cost-effective for large institutional investors, and institutions are likely to have more influence when they have large shares of ownership (Grossman and Hart 1980; Shleifer and Vishny 1986). At the same time, recent theoretical and empirical studies show that a shareholderinvestment horizon affects the extent to which shareholders effectively monitor firm managers (Chen, Harford, and Li 2007; Gaspar, Massa, and Matos 2005) and how shareholders design managerial incentives (Bolton, Scheinkman, and Xiong 2005, 2006; Dikolli, Kulp, and Sedatole 2006). Bolton, Scheinkman, and Xiong (2006), for example, provide a theoretical link between a shareholder investment horizon and the structure of CEO pay and show that optimal compensation contracts for CEOs in a speculative market weigh short-term performance more heavily when shareholders have shorter investment horizons.

In addition to direct involvement, institutions can affect a firms' executive-compensation policy through investing and trading decisions (i.e., clientele effects). Institutions with minor holdings may have little incentive to directly monitor, but if the board cares about the potential effects of the institutional selling of shares, the board may structure executive-compensation policies according to institutional investors' preferences to cater to specific types of 
institutional investors (Gillan and Starks 2003).

To investigate the effect of shareholder investment horizons on CEO compensation contracts, I test the following hypotheses: (1) greater short-term holdings are positively associated with the use of stock options and with the sensitivity of new option grants to stock price, (2) greater short-term holdings are associated with a more negative effect on CEO bonus compensation when a firm misses an earnings benchmark, (3) greater long-term holdings are negatively associated with the use of stock options and with the sensitivity of CEO equity incentives to stock price.

In line with regulators' and investors' concern that myopic investment behavior by some institutional investors may lead managers to focus on short-term earnings, the results provide evidence consistent with short-term investors creating pressures for the board of directors to structure executive compensation according to these short-term institutions' preferences (e.g., greater reliance on stock options that do not need to be expensed and larger annual bonus penalties for missing quarterly earnings benchmarks).

The results also indicate that short-term institutional ownership is positively related to new option-grants sensitivity to stock price, consistent with Bolton, Scheinkman, and Xiong (2006)'s theoretical prediction that firms with more short-horizon shareholders design compensation contracts to provide strong incentives for managers to boost a short-term speculative component in stock price. I also find that the greater long-term holdings are negatively associated with the use of stock options and with the sensitivity of CEO equity portfolio incentives to stock price, supporting the view that institutional monitoring induced by long-term-investment horizons substitutes for managerial incentives.

This paper makes three contributions to the literature. First, this study advances our understanding of the relation between short-term shareholders and board of directors' governance-related decisions. ${ }^{1)}$ My findings are consistent with short-term shareholders

1) Dikolli et al. (2006) also examine the relation between types of institutional investors and $\mathrm{CEO}$ compensation contracts. Focusing on the cash portion of $\mathrm{CEO}$ compensation, they test whether a board uses CEO compensation contracts that mitigate or cater to short-term investment horizons of transient institutions. My study complements Dikolli et al. (2006) by considering two important CEO compensation decisions that boards make: (1) CEO equity incentives and (2) subjective/individual evaluations of CEOs, proxied by penalties for missing earnings benchmarks. 
emphasizing short-term stock performance in the design of CEO compensation, supporting that myopic investment behavior will likely place undue pressures for short-term performance on the firms' boards of directors as they make governance decisions (Bushee 2004; Parrino, Sias, and Starks 2003).

Second, this study adds to the growing literature on the role that accounting plays in firms' design of CEO compensation contracts (Carter, Lynch, and Tuna 2007; Ferri, Sandino, and Markarian 2006; Hu 2006; Kimbrough and Louis 2004) by demonstrating that favorable accounting treatments of options drive short-term investors' preferences for the use of stock options.

Finally, prior research documents that institutional ownership concentration is positively related to pay-for-performance sensitivity from new option grants (Almazan, Hartzell, and Starks 2005; Hartzell and Starks 2003). I extend these studies by showing that the percentage ownership by short-term and long-term shareholders is also an important predictor of CEO incentives.

Recently, the U.S House of Representatives passed the "The Shareholder Vote on Executive Compensation Act" that mandates a nonbinding vote on executive compensation for every public company. My results suggest that to the extent that short-sighted shareholders have a say on CEO pay, CEOs will increase their attention to short-term profits to justify pay rather than investing in long-run business strategies.

The remainder of the paper is organized as follows. I review prior literature and develop my hypotheses in Section 2. In Section 3 and 4, I discuss my research design and present the results. Section 5 concludes.

\section{HYPOTHESES DEVELOPMENT}

Firms' ownership structure and its effect on corporate policies have received much attention from academic researchers (Cho 2009; Choi, Kwak, and Yoo 2007, 2008) Institutional investors are known to monitor their portfolio firms' governance practices by establishing proxy-voting policies, by voting proxies to counter firm-management positions, by filing shareholder proposals, and by initiating frequent contact with portfolio firm management (Gillan and Starks 2000). Recent evidence suggests that executive compensation is one of the 
key governance issues of concern to institutional investors (Davis and Kim 2007; Hartzell and Starks 2003; Rothberg and Lilien 2005; Hu 2006).

Although direct monitoring could be cost-effective for large institutional investors (Grossman and Hart 1980), the extent to which shareholders can monitor firms' management may also reflect other factors such as shareholders' investment horizons and liquidity concerns. Shareholders with longer horizons have more incentive to invest their resources in monitoring even if their stake is not large because they are likely to retain the investment and to reap the corresponding benefits from monitoring (Chen, Harford, and Li 2007; Gaspar, Massa, and Matos 2005).

While long-term shareholders will have lower monitoring costs, direct monitoring such as filing shareholder proposals can be prohibitively costly and time-consuming activities for short-term shareholders (Brandes, Hadani, and Goranova 2006). This is especially true insofar as shareholders typically face a series of legal and structural hurdles in influencing a board's governance-related decisions.

However, even shareholders with short horizon can "vote with their feet" when they are dissatisfied with a firm's governance practices such as executive compensation. ${ }^{2)}$ Chan and Lakonishok (1995) report evidence that the trading by high turnover institutions produces the largest stock price impacts. Bushee $(1998,2004)$ and Bushee and Noe (2000) have shown that short-term investors focus and trade on short-term earnings news, thereby creating high stock return volatility. Hotchkiss and Strickland (2003) document that stock price response to negative earnings news is more pronounced for firms with higher momentum institutional ownership.

Collectively, prior research findings document that investor composition influences the sensitivity of stock price to short-term performance, suggesting that clientele effect, through fear of certain institutional selling, could cause the board to make compensation decisions consistent with institutional preferences. To the extent that undervaluation caused by short-term institutional selling is costly to firms, the board may cater to short-term institutions by

2) Consistent with this argument, Parrino, Sias, and Starks (2003) find that firms that fired their CEO had a significantly greater decline in institutional ownership in the year prior to CEO turnover, and this finding supports the assertion that institutional selling influences a board's decisions. 
strategically structuring executive compensation practices according to short-term institutional investors' preferences.

\section{Short-Term Investors and Executive Compensation}

\section{Short-Term Investors and Stock Options.}

Firms with more shares held by short-term institutions are likely to grant more options to CEOs relative to other components of CEO pay. Until recently, the use of stock options did not require recording of an income-statement expense and few firms chose to voluntarily expense stock options. ${ }^{3)}$ Prior research documents that the accounting treatment of options motivated firms to use stock options (Carter, Lynch, and Tuna 2007; Core and Guay 1999; Kimbrough and Louis 2004; Matsunaga 1995).

In line with the effect that favorable accounting treatment of stock options (compared to that of restricted stocks and cash compensation) has on CEO pay mix, prior research demonstrates (1) that firms with higher capital market pressure are more likely to use stock options as executive-oriented rewards (Carter, Lynch, and Tuna 2007) and (2) that firms grant more options when doing so helps the firms meet certain earnings benchmarks (Kimbrough and Louis 2004). ${ }^{4}$ These findings suggest that firms facing capital market pressure will prefer using stock options to avoid recognizing compensation expenses ${ }^{5)}$ and this strategy will help the firms achieve

3) Aboody, Barth, and Kasznik (2004) identified 155 firms that voluntarily recognized stock-based compensation as an expense in 2002. However, this is not the case for S\&P 1500 firms covered by the ExecuComp database. For example, Carter, Lynch, and Tuna (2007) identify only one or two ExecuComp firms that, each year between 1998 and 2001, expensed stock options. Even for 2002, the final year of my sample period, I find that only thirty-two ExecuComp firms expensed options, and this finding suggests that a majority of my sample firms did not expense stock options during my sample period (1998-2002).

4) McConnell, Pegg, Mott, and Senyek $(2005,8)$ report that if the FASB required firms to expense employee stock options on income statements, the $2002 \mathrm{~S} \& \mathrm{P}$ 500 reported net income from continuing operations would have declined by $17 \%$ (Also see Botosan and Plumlee, 2001).

5) Although stock option expenses are disclosed in footnotes for non-expensing firms, prior research suggests that investors may place more weight on recognized amounts than on disclosed amounts (Espahbodi, Espahbodi, Rezaee, and Tehranian, 2002). Carter, Lynch, and Tuna (2007) find that firms both increase the use of restricted stocks and reduce options and that the firms make these decisions in line with the firms' decision to begin to expense options. This finding suggests that stock option accounting has played a key role in determining CEO 
a string of earnings increases and meet analysts' earnings forecasts, in turn, enjoy higher price-earnings multiples (Barth, Elliott, and Finn 1999; Carter and Lynch 2003). Thus, I expect that firms with more short-term institutional ownership are more sensitive to the expected costs of recording compensation expenses and thereby use more stock options.

Short-Term Investors and the Pay-for-Performance Sensitivity of Option Grants.

Firms with more shares held by short-term institutions are likely to grant stock options with higher sensitivity to stock price. Prior research documents that the CEOs with higher stock-based incentives may have incentive to manipulate earnings (Bergstresser and Philippon 2006; Burns and Kedia 2006; Cheng and Warfield 2005; Efendi, Srivastava, and Swanson 2007). Burns and Kedia (2006) find that stock options with higher sensitivity to stock price provide the CEO with stronger incentives to misreport compared to other components of CEO pay such as stocks. Bolton, Scheinkman, and Xiong (2006) analytically show that optimal managerial compensation contracts may weight short-term price performance at the expense of long-term value in a speculative market characterized by investors' heterogeneous beliefs.

Since the sensitivity of option grants to stock price provides the CEO with strong incentives to boost short-term earnings due to their convex payoffs (Burns and Kedia 2006), the firms with more short-term ownership could provide the CEO with stronger shortterm incentives by granting new options that are more sensitive to a change in stock price. Thus, I predict a positive relation between short-term institutional ownership and the sensitivity of new option grants to a firm's stock price.

Short-Term Investors and Bonus Penalty of Missing an Earnings Benchmark.

Shareholder investment horizons can influence other components of CEO pay such as annual bonus, which is often linked to accounting earnings. Managers cater to the investors' demand for positive earnings surprises (Rajgopal, Shivakumar, and Simpson 2007). Recent evidence suggests that managers are paying much

pay mix. 
attention to efforts to meet forecasted earnings benchmarks and that there are substantial penalties for firms that miss analysts' consensus earnings forecasts (Bartov, Givoly, and Hayn 2002; Graham, Harvey, and Rajgopal 2005; Kasznik and McNichols 2002; Skinner and Sloan 2002). In line with these findings, Matsunaga and Park (2001) document a significant incremental adverse effect on CEO annual cash bonuses when a firm's quarterly earnings fall short of either the consensus analyst forecast or the earnings for the same quarter of the prior year, after a general pay-for-performance relationship is controlled.

I predict that the boards of firms with higher short-term institutional ownership are likely to perceive greater costs when the firms miss analysts' forecasts. Prior research documents that a high level of short-term ownership is associated with the likelihood that firms will reduce R\&D in order to reverse an earnings decline (Bushee 998), with market pricing of near-term earnings (Bushee 2001), with the likelihood that firms will meet or exceed earnings benchmarks (Matsumoto 2002), with the likelihood that firms will use earnings restatements and discretionary accruals (Burns, Kedia, and Lipson 2006), and with market reaction to negative earnings news (Hotchkiss and Strickland 2003).

Overall, these findings suggest that boards of firms with higher short-term institutional ownership are likely more concerned about a negative earnings surprise and that they may punish the CEO more severely by exercising discretion over CEO compensation.

\section{Long-Term Investors and Executive Compensation}

Unlike short-term institutions, long-term institutions are ambiguous in relation to whether or not they prefer stock options. On the one hand, long-term institutions may prefer options because stock options provide CEOs with the incentive to increase firm value (Hanlon, Rajgopal, and Shevlin 2003) and to take more risks (Coles, Daniel, and Naveen 2006). On the other hand, granting stock options could lead to the dilution of shareholder values (Brandes, Hadani, and Goranova 2006; Ferri, Sandino, and Markarian 2006). As discussed earlier, CEOs with stock option compensation may have the greater incentives to manipulate earnings. Prior research also documents that CEOs with stock options strategically time the release of good and bad news (Aboody and Kasznik 2000; 
Yermack 1997), backdate stock options (Heron and Lie 2007; Lie 2005) and pursue investment projects that increase shortterm stock price performance at the expense of long-term value. Cornett, Marcus, and Tehranian (2007) find that the positive impact of option compensation on firm performance largely disappears when measured performance is adjusted for the effect of earnings management.

Since long-term institutions' preferences for executive compensation are unclear, it is unlikely that the board may cater to long-term institutions by strategically structuring CEO compensation. Long-term shareholders, however, will have more incentives to monitor their portfolio firms' executive compensation because the net benefits of monitoring increases with investment horizons (Chen, Harford, and Li 2007; Gaspar, Massa, and Matos 2005).

In line with standard agency theory suggesting that incentives and shareholder monitoring could substitute for each other (Engel, Gordon, and Hayes 2002; Ke, Petroni, and Safieddine 1999; Mehran 1995), I predict that long-term institutional ownership will be negatively related to the use of stock options and the payfor-performance sensitivity of CEO options and stocks portfolio incentives. To the extent that monitoring by long-term institutional shareholders is possible, there will be less demand for compensation contracts that impose greater risk through greater weights on equity-based incentives to CEOs.

\section{SAMPLE SELECTION AND VARIABLE CONSTRUCTION}

\section{Sample Selection}

My sample starts from the intersection of ExecuComp, CDA/ Spectrum, CRSP, COMPUSTAT, and the I/B/E/S during the 19922002 periods. I obtain CEO compensation data from ExecuComp, which covers companies from the S\&P 500, S\&P 400 mid-cap, and S\&:P 600 small-cap indices starting from 1992. I draw stock returns and accounting variables from CRSP and COMPUSTAT, respectively. I use the I/B/E/S database to obtain quarterly earnings forecasts. I obtain quarterly institutional ownership data from the CDA/ Spectrum database of $13 \mathrm{~F}$ filings. All investors with at least $\$ 100$ 
million in equity holdings are required to file $13 \mathrm{~F}$ forms with the SEC. I base the institutional-investment-horizon classification on Bushee (1998, 2001). For all subsequent analyses, I use institutional ownership data from the quarter that is closest to firms' fiscal-year end. I draw key governance variables from the IRRC database.

In order to reduce the effects of extreme observations, I winsorize the top and bottom 1 percent of the distributions of all continuous variables. My final sample consists of 9,433 firm-year observations from 1,848 distinct firms (referred to as the "full sample"). Since I include a set of governance variables as controls and those were available from the IRRC database only for the 1998-2002 period, I test some of my hypotheses using a "reduced sample" (4,031 firmyears from 1,154 distinct firms).

\section{Compensation Variables}

To fully capture the structure of CEO compensation, I employ four dependent variables. First, I use the ratio of the Black-Scholes value of stock options to CEO total compensation (\%Equity_grant) in order to examine the effect of institutional investor horizons on decisions regarding annual CEO pay mix.

Second, Hartzell and Starks (2003) test the association between institutional ownership concentration and pay-for-performance sensitivity of new option-grants using the dollar change in the value of the annual option grants for a $\$ 1,000$ change in shareholder wealth (Jensen and Murphy 1990; Yermack 1995). In order to make my results directly comparable to those of Hartzell and Starks (2003), I measure new option- grants sensitivity to price (Option_PPS) with the dollar change in the value of the annual option grant to the CEO for a $\$ 1,000$ change in shareholder wealth.

Third, I measure CEO equity incentives with the pay-forperformance sensitivity of CEO options and stocks portfolio including previously granted options and stocks (Core and Guay 1999). Following Core and Guay (1999), I use a percentage-change measure of CEO equity incentives (Equity_incen1) as my dependent variable that shall capture the dollar changes (in thousands) in CEO wealth for a $1 \%$ change in stock price. An alternative measure could be the dollar change in CEO wealth for a dollar change in firm value (Jensen and Murphy 1990). In order to ensure that my results are robust to the alternative measure of incentives, I also use the 
Jensen and Murphy (1990) fractional measure of incentives (Equity_ incen2).

Finally, consistent with Baber, Janakiraman, and Kang (1996) and Matsunaga and Park (2001), I use change in CEO annual bonus deflated by prior-year salary ( $\triangle$ Bonus) to test the influence of shortterm institutional investors through their pressures on the board's annual CEO bonus decisions.

\section{Institutional Investment Horizons Variables}

Bushee $(1998,2001)$ proposes classification of institutional investors on the basis of investment-horizon length: transient, quasi-indexers, and dedicated. ${ }^{6)}$ In his classification, "transient" institutions are characterized as having both high portfolio turnover and highly diversified portfolio holdings, as well as the highest use of momentum strategies. As such, the short investment horizons of these institutions create little incentive to actively monitor and influence firms' executive compensation practices, and I measure short-term institutions' ownership using transient institutions' ownership.

The other two types of institutions, "dedicated" and "quasi-indexers," reflect long-term, stable ownership by institutions. Dedicated institutions are characterized by high concentration, low turnover, and almost no trading sensitivity to current earnings. Quasi-indexers are also characterized by low turnover, but they tend to have diversified holdings and to use a buy-and-hold strategy for portfoliofund investments. I measure long-term institutions' ownership on the basis of the sum of quasi-indexers' and dedicated institutions' ownership. ${ }^{7)}$

6) Bushee (1998) created three constructs from nine key variables characterizing the past investment behavior of institutional investors using factor analysis. The BLOCK factor captures the average size of an institution's stake in its portfolio firms. The PTURN factor captures the extent to which an institution trades more frequently. The MOMEN factor captures the trading sensitivity to current earnings news. Then, scores from these factors are used to create three distinct classifications using cluster analysis.

7) Quasi-indexers are classified into Long because they are more likely to be engaged in monitoring. Their holdings are often so large that the shares cannot be sold without driving the price down and suffering further losses (Gillan and Starks, 2000). Furthermore, the fact that pension funds index a large portion of their portfolios precludes them from selling underperforming stocks. Bushee (2004) uses CALPERS as an example of quasi-indexers and CALPERS is indeed the one which has been the most visible in shareholder activism. 


\section{Descriptive Statistics and Univariate Correlations}

Panel A of table 1 presents descriptive statistics for the variables used in my analyses. I report institutional ownership variables on the basis of the "full sample" in table 1.

The mean institutional ownership in the sample firms is $59.2 \%$. This percentage is much higher than reported in previous studies (e.g., 35.8\% in Bushee, 2001) that used a COMPUSTAT sample in the years preceding this study's sample period. This figure suggests that ExecuComp firms, on average, are large and surviving firms with higher institutional ownership. The mean percentage holdings by short-term institutions (Short) and long-term institutions (Long) are $17.9 \%$ and $40.3 \%$, respectively. The mean proportion of institutional ownership accounted for by the five largest institutions (Concen_Top5) is $42.2 \%$, comparable to $44.0 \%$ reported by Hartzell and Starks (2003) and based on a 1992-1997 time period.

The mean and the median percentages of CEO compensation that are in the form of stock options are $40.2 \%$ and $40.6 \%$, respectively, and these figures suggest that the sample firms heavily rely on stock options as a vehicle by which the firms annually reward their CEOs. The mean and the median dollar values of CEO new option grants sensitivity is $\$ 2.39$ and $\$ 1.2$ per $\$ 1,000$, respectively. The mean and the median dollar values of CEO equity portfolio incentives (Equity_incen 1) are $\$ 1,036,600$ and $\$ 265,500$, respectively. These figures suggest that an average sample CEO is subject to huge potential gains and losses in response to a change in stock price. On average, CEOs of the sample firms own about $2.3 \%$ of total shares outstanding. The board, on average, consists of nine directors and meets seven times per year. The average fraction of compensation committee members independent of firm's management is $90.6 \%$.

Panel B of table 1 provides the frequency distribution of missedbenchmark variables. Although a majority of firms meet the benchmark for all four quarters or miss it just once, 34.8\% (analyst forecasts) and 35.5\% (same quarter of prior-year earnings) of firmyears miss their quarterly earnings benchmark more than once in a year.

Table 2 provides Pearson correlations among the institutional ownership variables and the key dependent variables. Not surprisingly, the percentage holdings by short-term institutions are 
Table 1. Descriptive Statistics

Panel A: Variables used in Empirical Analyses

\begin{tabular}{|c|c|c|c|c|c|c|}
\hline Variable & $\mathrm{N}$ & Mean & Std. Dev. & Q1 & Median & Q3 \\
\hline Tih & 9433 & 0.592 & 0.182 & 0.467 & 0.606 & 0.729 \\
\hline Short & 9433 & 0.179 & 0.132 & 0.076 & 0.147 & 0.256 \\
\hline$\Delta$ Short & 7585 & 0.023 & 0.096 & -0.027 & 0.014 & 0.067 \\
\hline Long & 9433 & 0.403 & 0.141 & 0.302 & 0.400 & 0.500 \\
\hline$\Delta$ Long & 7585 & -0.007 & 0.095 & -0.058 & -0.001 & 0.049 \\
\hline Concen_Top5 & 9433 & 0.422 & 0.131 & 0.330 & 0.403 & 0.490 \\
\hline$\triangle$ Bonus & 9433 & 0.083 & 0.810 & -0.168 & 0.033 & 0.356 \\
\hline$\Delta$ Earn & 9433 & 0.002 & 0.076 & -0.013 & 0.007 & 0.021 \\
\hline Ret & 9433 & 0.136 & 0.493 & -0.160 & 0.072 & 0.344 \\
\hline$\%$ Equity_grant & 4031 & 0.402 & 0.295 & 0.133 & 0.406 & 0.644 \\
\hline Equity_incen1 & 4031 & 5.617 & 1.594 & 4.575 & 5.582 & 6.655 \\
\hline Equity_incen2 & 4031 & 2.724 & 1.364 & 1.900 & 2.771 & 3.539 \\
\hline Option_PPS & 4031 & 2.392 & 3.935 & 0.250 & 1.234 & 3.041 \\
\hline Expense & 4031 & 0.006 & 0.078 & 0.000 & 0.000 & 0.000 \\
\hline Incen_residual & 4031 & 0.011 & 0.198 & -0.097 & 0.003 & 0.108 \\
\hline Noise_roa & 4031 & 0.041 & 0.048 & 0.013 & 0.025 & 0.050 \\
\hline Noise_ret & 4031 & 0.484 & 0.408 & 0.241 & 0.359 & 0.559 \\
\hline High_tax & 4031 & 0.340 & 0.474 & 0.000 & 0.000 & 1.000 \\
\hline Low_tax & 4031 & 0.085 & 0.279 & 0.000 & 0.000 & 0.000 \\
\hline Lev & 4031 & 0.248 & 0.175 & 0.097 & 0.251 & 0.369 \\
\hline Btm & 4031 & 0.524 & 0.380 & 0.255 & 0.448 & 0.685 \\
\hline Ownership & 4031 & 0.023 & 0.053 & 0.001 & 0.003 & 0.014 \\
\hline Size & 4031 & 7.495 & 1.624 & 6.317 & 7.333 & 8.582 \\
\hline New & 4031 & 0.127 & 0.333 & 0.000 & 0.000 & 0.000 \\
\hline$F c f$ & 4031 & 0.002 & 0.172 & -0.039 & 0.017 & 0.067 \\
\hline$B d \_s i z e$ & 4031 & 9.476 & 2.534 & 8.000 & 9.000 & 11.000 \\
\hline Num_mtg & 4031 & 7.001 & 2.650 & 5.000 & 6.000 & 8.000 \\
\hline Dual & 4031 & 0.716 & 0.451 & 0.000 & 1.000 & 1.000 \\
\hline Comp_ind & 4031 & 0.906 & 0.180 & 0.833 & 1.000 & 1.000 \\
\hline Tenure & 4031 & 7.042 & 6.994 & 2.000 & 5.000 & 10.000 \\
\hline Dir_own & 4031 & 0.090 & 0.136 & 0.004 & 0.033 & 0.119 \\
\hline SP500 & 4031 & 0.388 & 0.487 & 0.000 & 0.000 & 1.000 \\
\hline Beta & 4031 & 0.944 & 0.610 & 0.522 & 0.844 & 1.240 \\
\hline
\end{tabular}


Table 1. (Continued)

\begin{tabular}{l|c|c|c|c|c|c}
\hline \hline \multicolumn{1}{c|}{ Variable } & $\mathrm{N}$ & Mean & Std. Dev. & $\mathrm{Q} 1$ & Median & $\mathrm{Q} 3$ \\
\hline Idiosyn & 4031 & 0.028 & 0.012 & 0.019 & 0.026 & 0.034 \\
Loss & 4031 & 0.158 & 0.365 & 0.000 & 0.000 & 0.000 \\
M_ret & 4031 & 0.106 & 0.591 & -0.261 & 0.023 & 0.330 \\
Dp & 4022 & 0.013 & 0.019 & 0.000 & 0.006 & 0.020 \\
Ep & 4031 & 0.017 & 0.219 & 0.019 & 0.045 & 0.069 \\
Liq & 4031 & 0.144 & 0.141 & 0.064 & 0.100 & 0.168 \\
Sprating & 4031 & 4.833 & 2.559 & 4.000 & 5.000 & 6.000 \\
Sgr & 4029 & 0.099 & 0.318 & -0.025 & 0.062 & 0.171 \\
Cfo & 4031 & 0.117 & 0.150 & 0.050 & 0.096 & 0.157 \\
Shrs & 4031 & 4.283 & 1.286 & 3.309 & 4.052 & 5.082 \\
\hline Varable defnity
\end{tabular}

Variable definitions:

Tih = percentage of total institutional holdings;

Short = percentage of institutional holdings by transient investors;

Long $=$ percentage of the sum of institutional holdings by quasi-indexers and institutional holdings by dedicated institutional investors;

$\triangle$ Bonus = change in CEO's bonus deflated by prior year salary;

$\Delta$ Earn $=$ change in annual core earnings deflated by market value of equity at the beginning of the period;

Ret $=$ monthly compounded annual stock return;

Concen_Top $5=$ fraction of all institutional ownership held by the top 5 largest institutions (= Top5 holdings / Tih);

$\%$ Equity_grant $=$ the ratio of the Black-Scholes value of stock options to CEO total compensation at year $\mathrm{t}$;

Equity_incen 1 = natural log of the dollar change (in thousands) in the value of a CEO's total equity portfolio incentives for a $1 \%$ change in a firm's stock price as defined in Core and Guay (1999);

Equity_incen2 = natural log of the dollar change in the value of a CEO's total equity portfolio incentives for a $\$ 1,000$ change in shareholder wealth defined in Jensen and Murphy (1990);

Option_PPS = the dollar change in the value of the annual option grant to the CEO for a $\$ 1,000$ change in shareholder wealth;

Expense $=1$ if the firm voluntarily expense options, and 0 otherwise;

Incen_residual $=$ natural log of $($ actual $\mathrm{CEO}$ equity incentive level $/$ predicted $\mathrm{CEO}$ equity incentive level) for year $\mathrm{t}-1$, where predicted equity incentive level is estimated from a prediction model by Core and Guay (1999);

Noise_roa $=$ time-series standard deviation of the firm's return on asset ratio over the prior 5 years at year $t$;

Noise_ret $=$ time-series standard deviation of the firm's annual stock return over the prior 5 years at year $t$; 


\section{Table 1. (Continued)}

High_tax $=1$ if the firm has a positive pretax book income and no net operating loss carry-forwards, and 0 otherwise;

Low_tax $=1$ if the firm has a negative pretax book income and net operating loss carry-forwards, and 0 otherwise;

$L e v=$ book value of liabilities divided by its book value of assets at year $t$;

$B t m=$ book to market ratio defined as its book value of equity divided by market value of equity;

Ownership = percentage of common shares owned by its CEO at year t;

Size $=$ the natural log of market value of equity defined as the firm's price per share at year t's fiscal year end (Compustat data item 199) multiplied by the number of shares outstanding (Compustat data item 25);

New $=1$ if the firm is a new-economy firm (new-economy firms are firms with SIC codes 3570, 3571, 3572, 3576, 3577, 3661, 3674, 4812, 4813, $5045,5961,7370,7371,7372,7373)$, and 0 otherwise;

Fcf $=$ sum of the firm's net operating cash flow (Compustat data item 308) and net investing cash flow (Compustat data item 311) scaled by market value of equity;

$B d \_s i z e=$ the number of board of directors at year $t$;

Num_mtg = the number of the board meetings during year $t$;

Dual $=1$ if the CEO is the chairman of the Board and 0 otherwise;

Comp_ind = percentage of independent directors on compensation committee;

Tenure $=$ number of years the firm's CEO has held office at year $t$;

Dirown $=\left(1000^{*}\right.$ the sum of number of stock options and number of shares granted to independent directors) divided by number of shares outstanding at year $t$;

Negfe $(J)=1$ if earnings were below the consensus analyst forecast for exactly $\mathrm{J}$ quarters during the year and 0 otherwise;

Decrease $(J)=1$ if earnings were below earnings for the same quarter for the previous year for exactly $\mathrm{J}$ quarters and 0 otherwise;

Beta $=$ the market model beta, estimated over a maximum 60 and minimum of 12 months;

Idiosyn = unsystematic risk, defined as the standard deviation of daily market model residuals over the prior year;

Loss $=1$ if the firm reports net loss, and 0 otherwise;

$M \_r e t=$ the market adjusted return;

$D p=$ dividend-to-price ratio;

$E p=$ earnings-price-ratio;

Liq $=$ average monthly trading volume divided by shares outstanding over the year;

SPrating $=$ S\&P common stock rating;

$S g r=$ sales growth relative to previous year;

$C f o=$ cash flow form operations;

Shrs = natural log of shares outstanding; 
Table 1. (Continued)

Panel B: Frequency Distribution of Missed Benchmark Dummy Variables (N $=9,433$ )

\begin{tabular}{c|c|c}
\hline \hline \multirow{2}{*}{ \# of Quarters Missed } & \multicolumn{2}{|c}{ \# of Observations (\%) Earnings Benchmark } \\
\cline { 2 - 3 } & Analyst Forecast & Prior Year Earnings \\
\hline 0 & $3,408(36.1 \%)$ & $4,321(45.8 \%)$ \\
1 & $2,739(29.0 \%)$ & $1,767(18.7 \%)$ \\
2 & $1,861(19.7 \%)$ & $1,405(14.9 \%)$ \\
3 & $1,049(11.1 \%)$ & $1,063(11.3 \%)$ \\
4 & $376(4.0 \%)$ & $877(9.3 \%)$ \\
\hline
\end{tabular}

Actual earnings per share and the latest consensus earnings forecast are obtained from the I/B/E/S.

negatively correlated with those by long-term institutions.

\section{EMPIRICAL MODELS AND RESULTS}

Influence of Institutional Investment Horizons on the Use of Stock Options in Annual CEO Compensation

In this section, I test whether the composition of institutional ownership is associated with annual CEO compensation decisions.

$$
\begin{aligned}
& \text { \%Equity_grant } \text { Ert }_{i, t}=\beta^{+} \beta_{1} \text { Short }_{i, t}+\beta_{2} \text { Expense }_{i, t}+\beta_{3} \text { Short }^{*} \text { Expense }_{i, t} \\
& +\beta_{4} \text { Concen_Top } 5_{i, t}+\beta_{5} \text { Incen_residual }{ }_{i, t-1} \\
& +\beta_{6} \ln (\text { Idiosyn })_{i, t}+\beta_{7} \text { Noise_roa }_{i, t}+\beta_{8} \text { Noise_ret }_{i, t} \\
& +\beta_{9} \text { High_tax }_{i, t}+\beta_{10} \text { Low_tax }_{i, t}+\beta_{11} \text { Lev }_{i, t}+\beta_{12} \text { Btm }_{i, t} \\
& +\beta_{13} \text { Ownership }_{i, t}+\beta_{14} \text { Size }_{i, t}+\beta_{15} \text { New }_{i, t}+\beta_{16} F c f_{i, t} \\
& +\beta_{17} \ln \left(B d \_ \text {size }\right)_{i, t}+\beta_{18} \ln \left(N u m \_ \text {mtg }\right)_{i, t}+\beta_{19} \text { Dual }{ }_{i, t} \\
& +\beta_{20} \text { Comp_ind }_{i, t}+\beta_{21} \text { Tenure }_{i, t}+\beta_{22} \text { Dirown }_{i, t} \\
& +\sum_{j=1}^{4} \beta_{j+22} \text { Year }+\sum_{j=1}^{13} \beta_{j+26} \text { Industry }+\varepsilon_{i, t}
\end{aligned}
$$

\%Equity_grant $_{i, t}=\beta^{+} \beta_{1}$ Long $_{i, t}+\beta_{2}$ Expense $_{i, t}+\beta_{3}$ Concen_Top $_{i, t}$

$+\beta_{4}$ Incen_residual $_{i, t-1}+\beta_{5}$ Noise_roa $_{i, t}+\beta_{6}$ Noise_ret $_{i, t}$

$+\beta_{7}$ High_tax $_{i, t}+\beta_{8}$ Low_tax $_{i, t}+\beta_{9} \operatorname{Lev}_{i, t}+\beta_{10}$ Btm $_{i, t}$

$+\beta_{11}$ Ownership $_{i, t}+\beta_{12}$ Size $_{i, t}+\beta_{13}$ New $_{i, t}+\beta_{14} F c f_{i, t}$ 

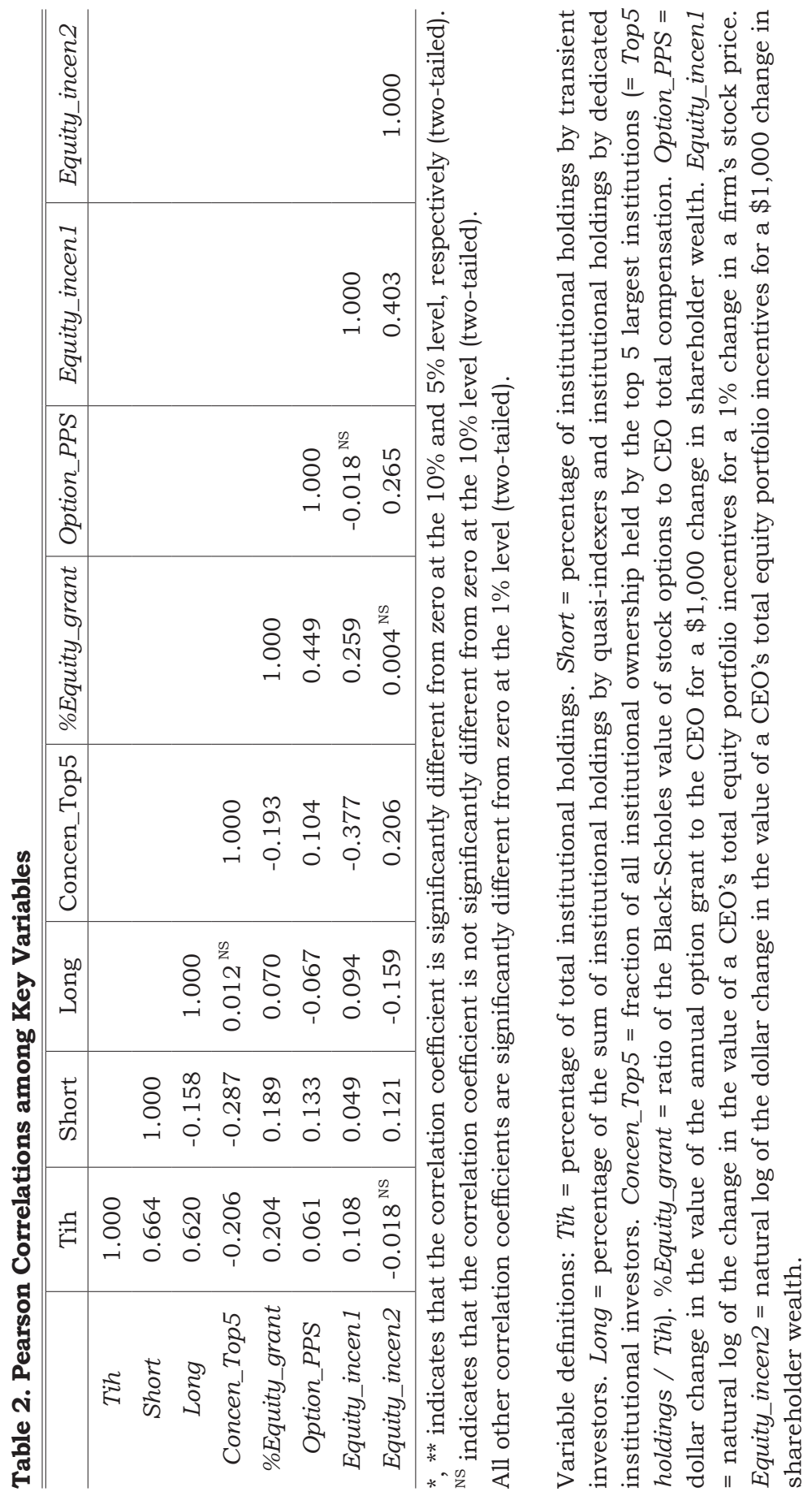


$$
\begin{aligned}
& +\beta_{15} \text { ln }(\text { Bd_size })_{i, t}+\beta_{16} \text { ln }(\text { Num_mtg })_{i, t}+\beta_{17} \text { Dual }_{i, t} \\
& +\beta_{18} \text { Comp_ind }_{i, t}+\beta_{19} \text { Tenure }_{i, t}+\beta_{20} \text { Dirown }_{i, t} \\
& +\sum_{j=1}^{4} \beta_{j+20} \text { Year }+\sum_{j=1}^{13} \beta_{j+24} \text { Industry }+\varepsilon_{i, t} \\
& (t=1998-2002)
\end{aligned}
$$

See table 1 for variable measurement. I predict that percentage holdings by short-term (long-term) institutions are positively (negatively) associated with the percentage of CEO compensation in the form of stock options (\%Equity_grant). To compare OLS results with 2SLS results that will be discussed later, I estimate two separate regressions that use short-term institutions' percentage holdings (Short) and long-term institutions' percentage holdings (Long) as explanatory variables, respectively. In all OLS-regression specifications in this paper, I use Huber-White robust standard errors clustered by firm. These standard errors are robust to both serial correlation and heteroskedasticity (Rogers 1993).

To examine the role of stock option accounting as a driver of short-term institutions' preference for firms' use of stock options, I create an indicator variable, Expense, which takes on either the value of 1 if the firm voluntarily expenses options or the value 0 otherwise. ${ }^{8)}$ I include Expense for both of the regressions and add an interaction term between Expense and Short in equation 1. In equation 1, I additionally control for firms' idiosyncratic risk (Idiosyn) to rule out the possibility that higher-stock-return volatility caused by short-term institutions drives the association between \%Equity_ grant and Short (e.g., Bushee and Noe 2000). ${ }^{\text {9) }}$

8) I obtained from McConnell, Pegg, Mott, and Senyek (2004) a list comprising 842 companies that had adopted option expensing under SFAS 123. From that list, I identified the ExecuComp firms that had chosen to expense options during my sample period.

9) Without controlling for stock return volatility, the association between short-term institutional ownership and firms' use of options may simply capture a secondorder effect of stock return volatility on the use of stock options, as suggested by Bushee and Noe (2000). A challenge here is that stock return volatility is one of key direct inputs in calculating the Black-Scholes value of option, suggesting that including stock return volatility as a control is likely to introduce a mechanical relation between stock return volatility and the dependent variable, \%Equity_ grant. To tackle this problem, I control for firms' idiosyncratic risk (Idiosyn) because Bushee and Noe $(2000,199)$ show that their results are unchanged when stock return volatility is replaced with unsystematic risk. 
For both of the regressions, I include the fraction of institutional ownership accounted for by the five largest institutions (Concen Top5) to control for institutional ownership concentration (Hartzell and Starks 2003). I build on prior research and include a comprehensive set of economic determinants of firms' use of stockbased compensation as control variables.

Core and Guay (1999) suggest that new options grants are related to the degree to which the CEO's equity portfolio deviates from optimal incentives. Thus, I include the deviation of $\mathrm{CEO}$ equity portfolio from optimal level in prior year (Incen_residual $t_{t-1}$ ), following Core and Guay (1999). I also include firm size, tenure, growth opportunities, tax-related incentives, prior CEO ownership, new economy indicator variable, and cash constraints (Bryan, Hwang, and Lilien 2000; Carter, Lynch, and Tuna 2007; Core and Guay 1999; Ittner, Larcker, and Lambert 2003; Murphy 2003; Smith and Watts 1992; Yermack 1995).

Prior research also documents that firms' governance plays a role in determining executive pay mix (Hanlon, Rajgopal, and Shevlin 2003; Mehran 1995) and it is indeed possible that institutions may influence CEO compensation indirectly through improved governance. Thus, I use detailed governance variables drawn from the IRRC database during the 1998-2002 period to control for the effect of firms' governance on the use of stock options. I include board size (Bd_size), the number of board meetings (Num_mtg), the fraction of independent directors on compensation committee (Comp_ ind), and CEO duality (Dual) (i.e., the CEO also serves as chairman of the board of directors).

Table 3 reports the estimation results for equations 1 and 2 . Columns 1 and 2 report OLS estimation results and columns 3 and 4 report two-stage least square (2SLS) results discussed in the appendix. ${ }^{10)}$ Consistent with prior research, the percentage of stock options in CEO annual compensation is positively correlated with

10) The TOBIT model is also widely used in the literature (e.g., Yermack, 1995; Hartzell and Starks, 2003) when a dependent variable is one that is roughly continuous over strictly positive values but zero for a non-trivial fraction of the population. Because not every firm grants stock options to its CEO every year, 20.1\% of \%Equity_grant in my sample takes on the value of zero. Thus, I estimate the equations 1 and 2 by using the TOBIT model, and the results remain unchanged. I also estimate a firm fixed-effects model to control for the effect of unobserved firm heterogeneity (Himmelberg, Hubbard, and Palia 1999). The results are similar to those reported in columns 1 and 2 in table 3. 
firm size, volatility, and the new economy indicator variable, but negatively correlated with the deviation of CEO equity portfolio from optimal level in prior year, the high-tax indicator variable, prior stock ownership, free cash flow, and CEO tenure.

OLS estimation results (columns 1 and 2) indicate that the percentage holdings by short-term institutions (Short) are significantly positively related to the percentage of CEO option compensation, even after a comprehensive set of economic and governance determinants of the use of stock-options is controlled for ( $t$-statistic $=3.19$, two-tailed), supporting my prediction. This finding is consistent with short-term institutions' focus on shortterm earnings - $a$ focus that encourages firms to use stock options that need not be expensed. This use, in turn, creates an increase in options for annual CEO pay mix decisions (Carter, Lynch, and Tuna 2007; Kimbrough and Louis 2004).

However, this positive relation between Short and \%Equity_ grant does not hold for firms that voluntarily expense options, as evidenced by the non-significance of coefficients $\left(\beta_{1}+\beta_{3}\right)$. In firms that choose to voluntarily expense stock options, the board does not appear to cater to short-term institutions' incentives in structuring CEO pay.

Contrary to my prediction, the percentage holdings by long-term (Long) are significantly positively correlated with the percentage of stock-option compensation (t-statistic $=2.06$, two-tailed). These findings, however, should be interpreted with caution owing to a potentially endogenous relation between institutional ownership and CEO pay mix. ${ }^{11)}$

To address potential endogeneity issues, columns 3 and 4 present two-stage least square results from an estimation of simultaneous equations that explicitly consider the possibility that institutional ownership and CEO pay mix are jointly determined (see appendix). ${ }^{12)}$

11) It is possible that firms adopt specific compensation policies to attract certain types of institutional investors in response to institutional investors' stock preferences. For example, short-term (long-term) institutional investors are more (less) likely to have a preference for stocks from firms that heavily rely on stock options (e.g., high \%Equity_grant).

12) Venkatachalam (2000) points out the potential endogeneity issue between institutional holdings and a researcher's variables of interest, and recommends a simultaneous estimation technique. It is well known in the econometrics literature that low explanatory power in first-stage estimation causes second-stage coefficient estimates to have large sampling variance. However, the explanatory power 


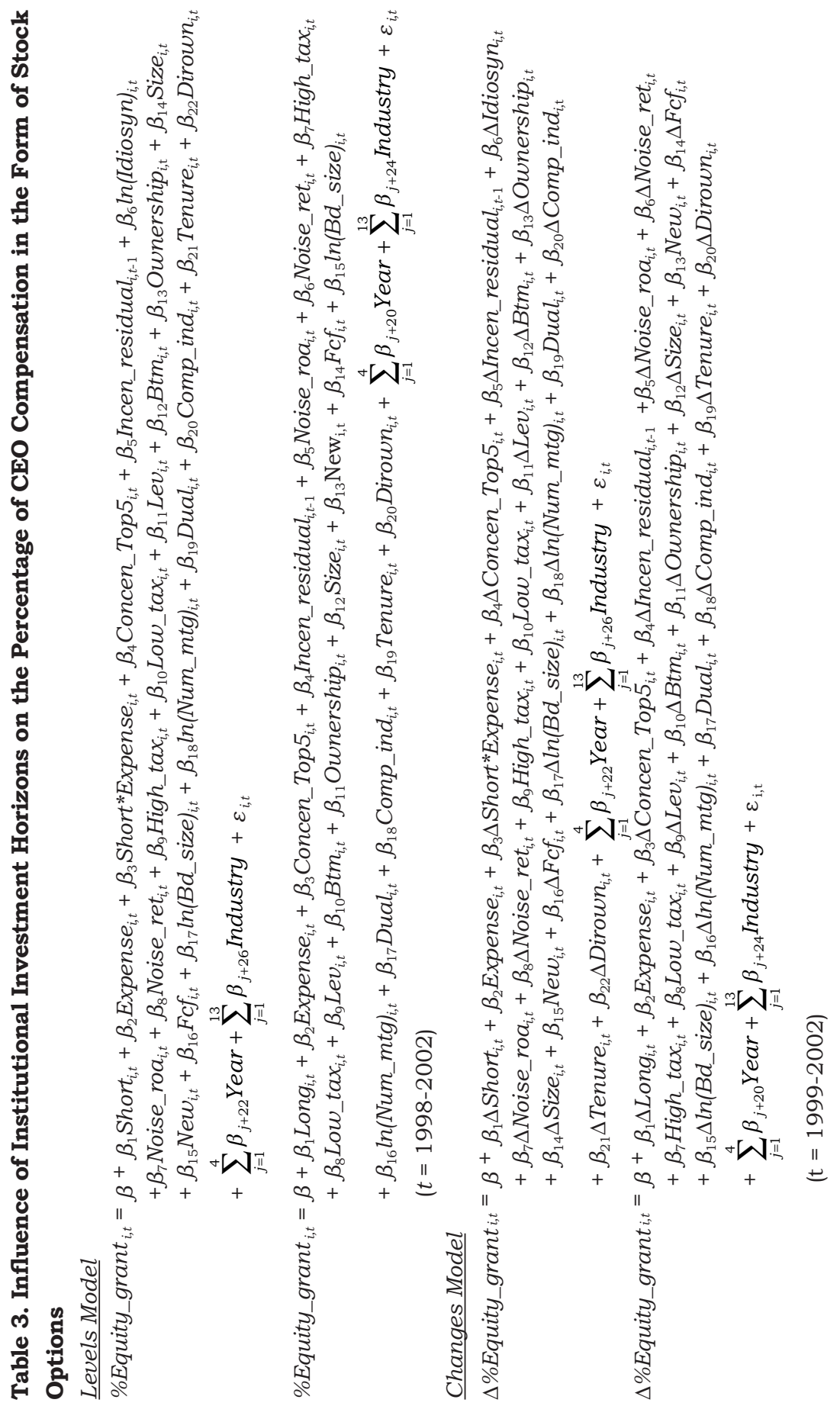




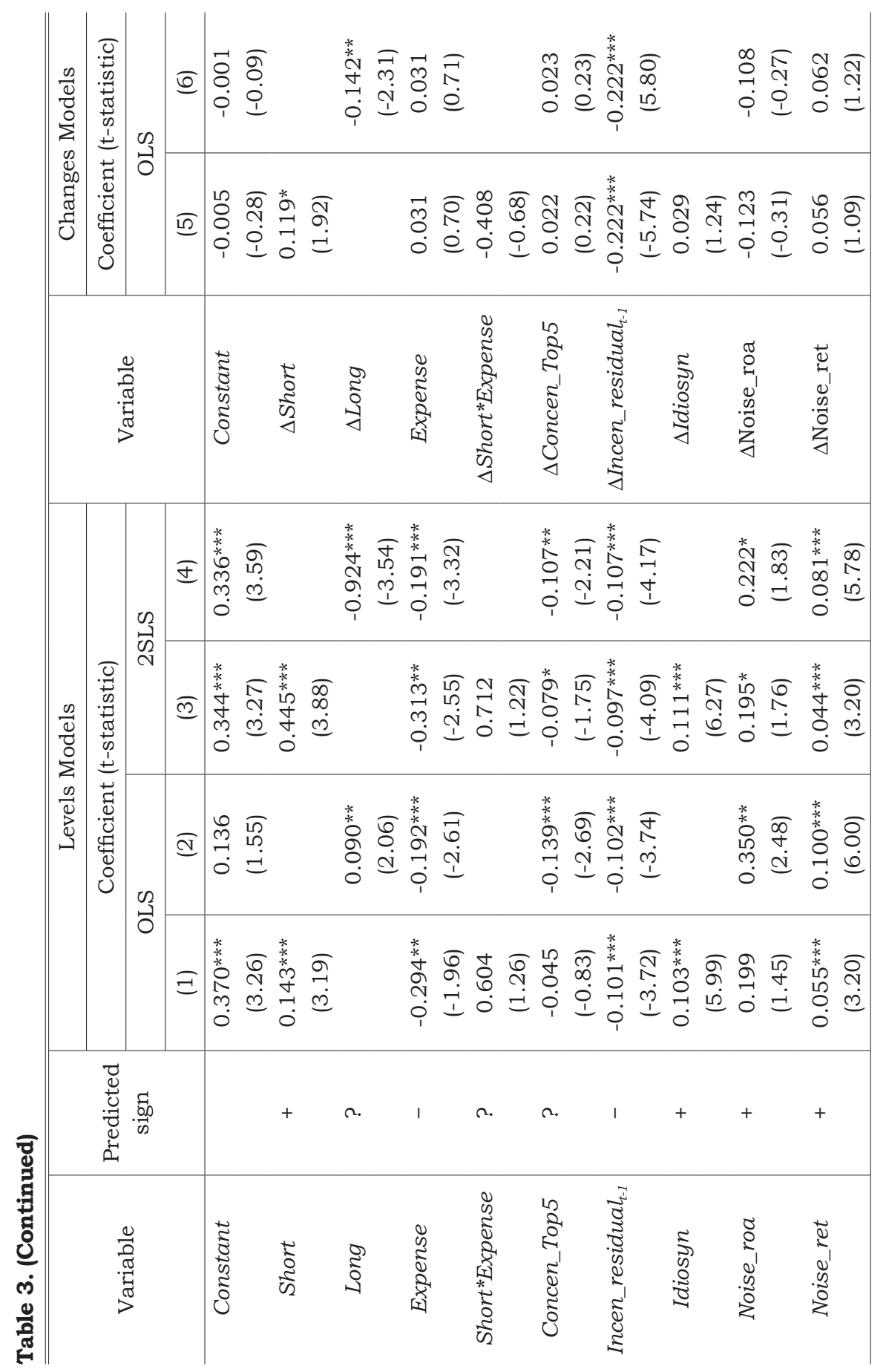




\begin{tabular}{|c|c|c|c|c|}
\hline & & \multirow{2}{*}{$\begin{array}{l}\Omega \\
0 \\
0\end{array}$} & $\bar{\sigma}$ & 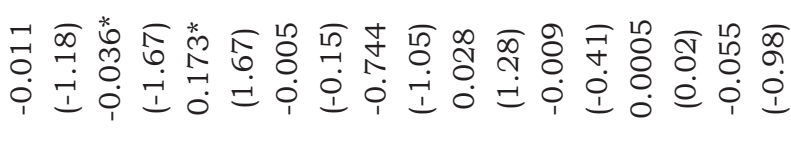 \\
\hline & & & $\underline{\square}$ & 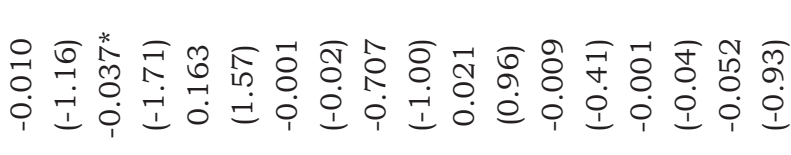 \\
\hline \multicolumn{4}{|c|}{ 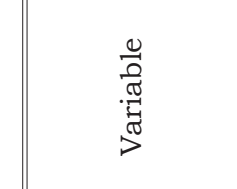 } & 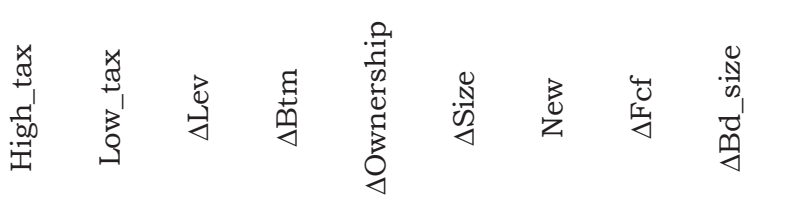 \\
\hline \multirow{4}{*}{ 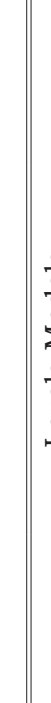 } & & \multirow{2}{*}{$\begin{array}{l}\tilde{D} \\
\vec{v} \\
\mathcal{N}\end{array}$} & $\Phi$ & 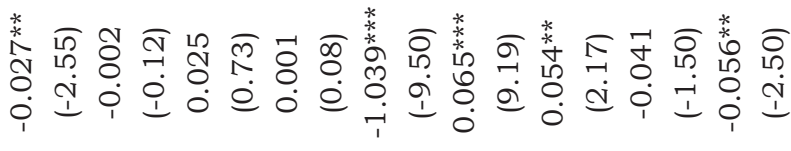 \\
\hline & & & लె & 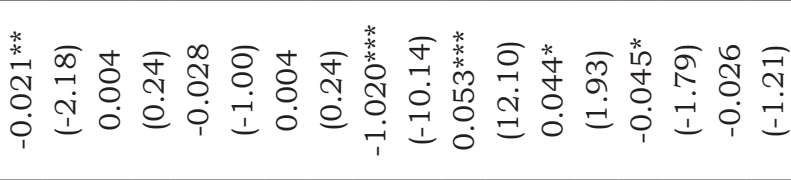 \\
\hline & & & $\widehat{\mathcal{I}}$ & 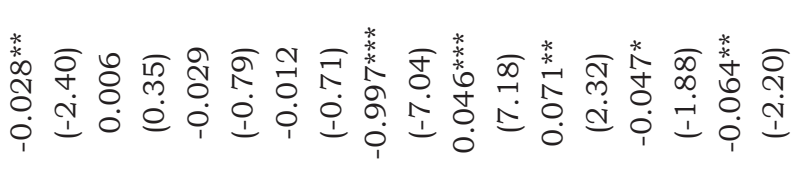 \\
\hline & & & $\Xi$ & 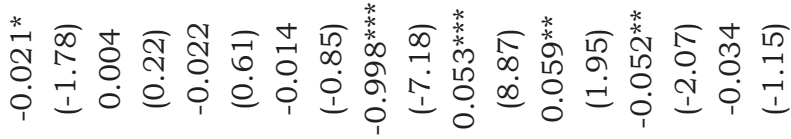 \\
\hline \multirow[b]{2}{*}{ 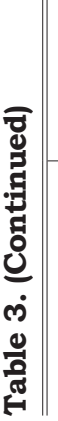 } & & 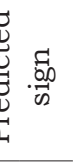 & & n. \\
\hline & \multicolumn{2}{|r|}{ 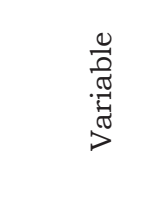 } & & 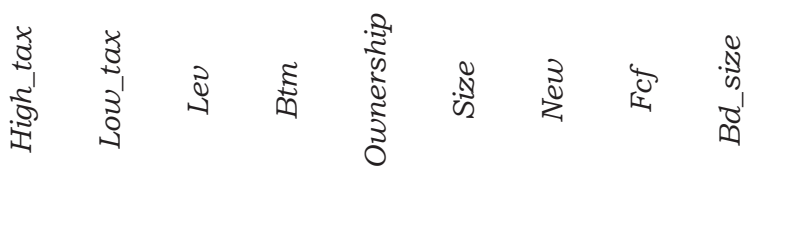 \\
\hline
\end{tabular}




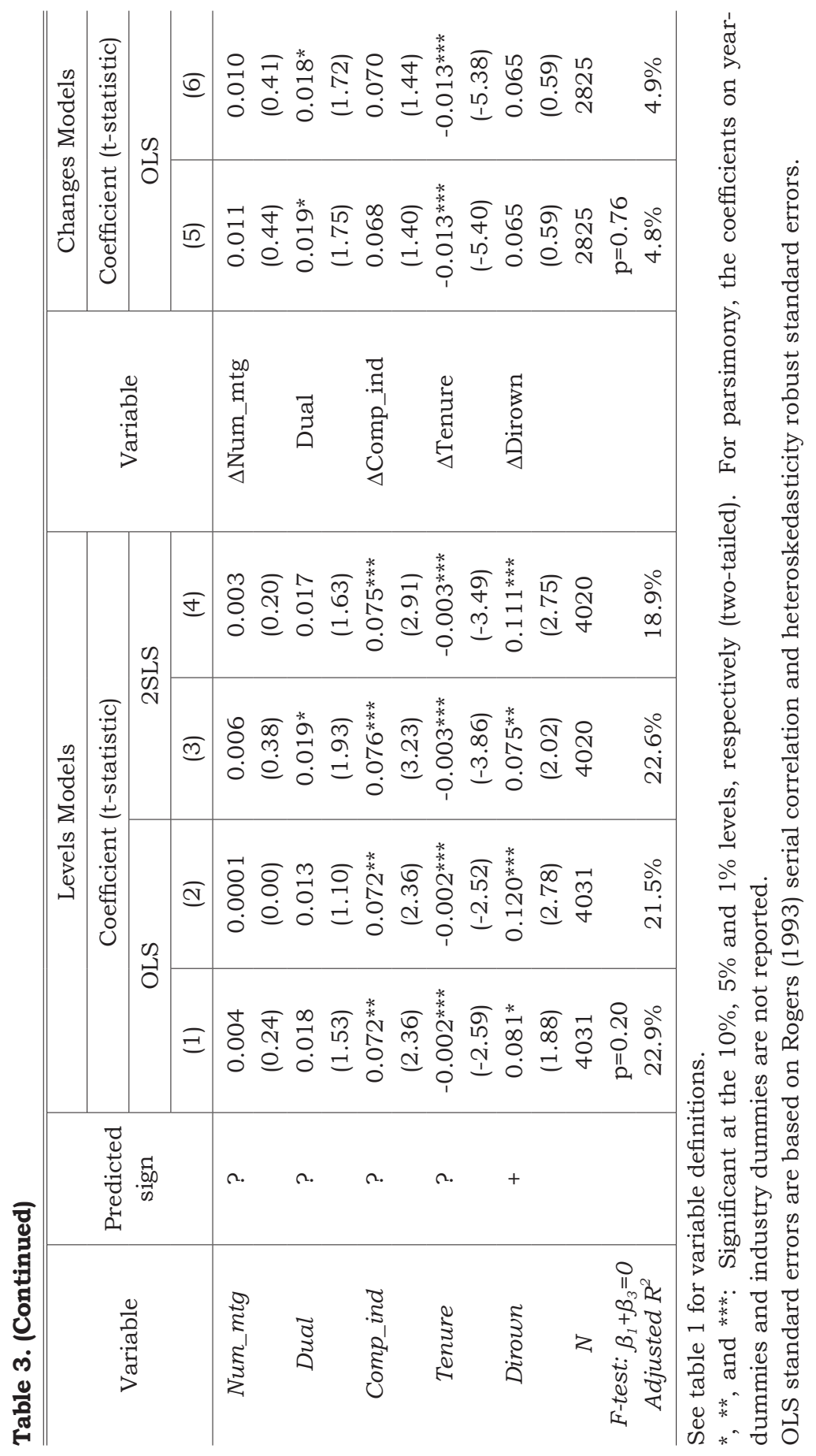


Overall, the results confirm the previous OLS regression results with respect to short-term institutions (Short): the percentage holdings by short-term institutions are positively associated with the percentage of option compensation after potential simultaneity bias is controlled for.

However, in contrast to the results in column 2, the percentage holdings by long-term institutions are negatively associated with the percentage of stock option compensation (t-statistic $=-3.54$, twotailed). This finding suggests that the previous result in column 2 with respect to the positive relation between Long and \%Equity_ grant is driven by potential simultaneity bias.

Finally, to further test the robustness of these findings, I take first differences in equations 2 and 3 and run OLS regressions. Columns (5) and (6) present OLS estimation results of first-differenced models. Again, the results confirm the previous levels regression results: change in the percentage holdings by short-term (long-term) institutions is positively (negatively) associated with the percentage of CEO stock option compensation. Collectively, the results in table 3 provide evidence consistent with the idea that the boards of firms consider shareholders' preferences regarding annual CEO compensation decisions and cater to certain types of institutional investors by structuring annual CEO pay mix decisions according to shareholders' preferences.

\section{Influence of Institutional Investment Horizons on Pay-for-Performance Sensitivity of CEO New Option Grants}

To test my prediction, I estimate the following TOBIT regression equation, following Hartzell and Starks (2003).

$$
\begin{aligned}
\text { Option_PPS }_{i, t}= & \beta+\beta_{1} \text { Concen_Top }_{i, t}+\beta_{2} \text { Inst_Hor }_{i, t}+\beta_{3} \text { Mkt_Cap } \\
& +\beta_{4} \text { Tobin's }_{\mathrm{i}, \mathrm{t}}+\beta_{5} \Delta \text { Shareholder_Wealth } \\
& +\sum_{j=1}^{3} \beta_{j+5} \text { Year }+\sum_{j=1}^{13} \beta_{j+8} \text { Industry }+\varepsilon_{i, t} \\
& (\mathrm{t}=1999-2002)
\end{aligned}
$$

Where: Inst_Hor represents Short and Long.

of the first-stage regressions ranges from $21.9 \%$ to $44.4 \%$, a range that mitigates potential inference problems. 
See table 1 for variable measurement. Hartzell and Starks (2003) find that both institutional ownership concentration (Concen_Top5) and total institutional holdings (Tih) are positively related to new option-grants sensitivity for top-five highly paid executives. I first replicate their findings in order to see if their results hold for my CEOs-only sample and then divide total institutional ownership according to investment horizons to examine the effect of investment horizons on the sensitivity of new option-grants.

Table 4 reports the TOBIT estimation results for equation 3 . Column 1 reports the replication results of Hartzell and Starks (2003). Overall, the results are consistent with those reported in Hartzell and Starks (2003). Both institutional ownership concentration (Concen_Top5) and total institutional ownership (Tih) are positively associated with the sensitivity of option grants to stock price.

Column 2 reports the results when Tih is replaced with Short and Long. Consistent with my hypothesis, Short is positively related to the sensitivity of option-grants to stock price $(\mathrm{p}<0.01$, two-tailed) but Long is negatively related to option-grant sensitivity $(\mathrm{p}<0.01$, two-tailed). This result is consistent with Bolton, Scheinkman, and Xiong (2006)'s prediction that short-term institutions influence the board so that CEO compensation contract puts more weights on short-term performance through granting options that are more sensitive to stock price. A negative coefficient on Long may reflect long-term oriented shareholders' incentives to monitor or their fear of the consequences of potential earnings manipulations induced by the sensitivity of options to stock price.

In a recent study, Smith and Swan (2007) argue that the positive relationship between institutional concentration and option-grants pay-for-performance sensitivity documented by Hartzell and Starks (2003) is sensitive to the measurement of firm size proxy. Smith and Swan (2007) conjecture and show that Hartzell and Starks's measure of institutional concentration is strongly negatively correlated with the natural logarithm of market capitalization. ${ }^{13)}$ To address this concern, I re-estimate the Hartzell and Starks regression using the natural logarithm of market capitalization as

13) Consistent with their conjecture, the correlation between Concen_Top5 and Size in my sample is -0.55 . 
Table 4. Influence of Institutional Investment Horizons on the Pay-forPerformance Sensitivity of New Option Grants

Option_PPS ${ }_{i, t}=\beta+\beta_{1}$ Concen_Top $5_{i, t}+\beta_{2}$ Inst_Hor ${ }_{i, t}+\beta_{3} M k t \_C a p_{i, t}+\beta_{4}$ Tobin's $Q_{i, t}$

\begin{tabular}{|c|c|c|c|c|c|}
\hline \multirow[b]{2}{*}{ Variable } & \multirow[b]{2}{*}{$\begin{array}{l}\text { Predicted } \\
\text { sign }\end{array}$} & \multicolumn{4}{|c|}{ TOBIT estimation } \\
\hline & & $\begin{array}{c}(1) \\
\text { Coefficient } \\
\text { (p-value) }\end{array}$ & $\begin{array}{c}\text { (2) } \\
\text { Coefficient } \\
\text { (p-value) }\end{array}$ & $\begin{array}{c}(3) \\
\text { Coefficient } \\
\text { (p-value) }\end{array}$ & $\begin{array}{c}(4) \\
\text { Coefficient } \\
\text { (p-value) }\end{array}$ \\
\hline Constant & & $\begin{array}{l}0.256 \\
(0.67)\end{array}$ & $\begin{array}{l}0.558 \\
(0.35)\end{array}$ & $\begin{array}{l}6.284 * * * \\
(0.00)\end{array}$ & $\begin{array}{l}5.406 * * * \\
(0.00)\end{array}$ \\
\hline Concen_Top5 & + & $\begin{array}{l}2.078 * * * \\
(0.00)\end{array}$ & $\begin{array}{l}3.463 * * * \\
(0.00)\end{array}$ & $\begin{array}{c}-1.386 \text { * } \\
(0.09)\end{array}$ & $\begin{array}{l}0.109 \\
(0.90)\end{array}$ \\
\hline Tih & + & $\begin{array}{l}1.411^{* * *} \\
(0.01)\end{array}$ & & $\begin{array}{l}2.190 * * * \\
(0.00)\end{array}$ & \\
\hline Short & + & & $\begin{array}{l}5.385 * * * \\
(0.00)\end{array}$ & & $\begin{array}{l}4.432 * * * \\
(0.00)\end{array}$ \\
\hline Long & - & & $\begin{array}{l}-2.267 * * * \\
(0.00)\end{array}$ & & $\begin{array}{r}-0.325 \\
(0.66)\end{array}$ \\
\hline Mkt_Cap & & $\begin{array}{c}-0.0001 * * * \\
(0.00)\end{array}$ & $\begin{array}{c}-0.0001 * * * \\
(0.00)\end{array}$ & & \\
\hline Tobin's $Q$ & & $\begin{array}{r}-0.080 \\
(0.13)\end{array}$ & $\begin{array}{c}-0.095 \text { * } \\
(0.07)\end{array}$ & $\begin{array}{l}0.037 \\
(0.49)\end{array}$ & $\begin{array}{l}0.006 \\
(0.91)\end{array}$ \\
\hline $\log ($ Mkt_Cap) & & & & $\begin{array}{l}-0.662 \text { *** } \\
(0.00)\end{array}$ & $\begin{array}{l}-0.538 * * * \\
(0.00)\end{array}$ \\
\hline $\begin{array}{c}\Delta \text { Shareholder } \\
\text { Wealth }\end{array}$ & & & $0.0001 *$ & 0.0001 & 0.0001 \\
\hline & & $(0.02)$ & $(0.06)$ & $(0.38)$ & $(0.37)$ \\
\hline $\begin{array}{r}\% \text { of non-cen } \\
\mathrm{N}\end{array}$ & ed obs & $\begin{array}{r}81.1 \% \\
3042\end{array}$ & $\begin{array}{r}81.1 \% \\
3042\end{array}$ & $\begin{array}{r}81.1 \% \\
3042\end{array}$ & $\begin{array}{r}81.1 \% \\
3042\end{array}$ \\
\hline
\end{tabular}

*, **, and ***: Significant at the $10 \%, 5 \%$ and $1 \%$ levels, respectively (two-tailed). For parsimony, the coefficients on year-dummies and industry dummies are not reported.

Mkt_Cap = market value of the firm (millions). Tobin's $Q=$ market value of the firm's assets scaled by the book value of the firm at year $t$. $\Delta$ Shareholder Wealth $=$ Change in the number of outstanding shares multiplied by the fiscal year end price from year $t-1$ to $t$. See table 1 for definitions of other variables. 
a size control in columns 3 and 4 instead of the level of market capitalization as in columns 1 and 2 .

The results in column 3 show that the sign of the coefficient on Concen_Top 5 flips and becomes less significant when the natural logarithm of market capitalization is used as a size control. Tih, however, continues to be positive and significant. When Tih is replaced with Short and Long in column 4, the coefficient on Concen Top5 is not statistically significant. Short continues to be positively related to the sensitivity of option grants to stock price $(\mathrm{p}<0.01$, two-tailed) but Long is not significantly related to option sensitivity any longer, suggesting that the positive coefficient on Tih in column 3 appears to be driven by Short. These results are consistent with Smith and Swan (2007) documenting that Hartzell and Starks' results are sensitive to the measurement of market capitalization as a control variable. Collectively, the results support that short-term institutions influence the board so that $\mathrm{CEO}$ compensation contract puts more weights on short-term performance through granting options that are more sensitive to stock price.

\section{Influence of Institutional Investment Horizons on Pay-for-Performance Sensitivity of CEO Equity Portfolio Incentives}

To test my prediction, I estimate the following regression equation, extending Core and Guay (1999).

$$
\begin{aligned}
\text { Equity_incen }_{i, t}= & \beta+\beta_{1}{\text { Concen_Top } 5_{i, t}+\beta_{2} \text { Inst_Hor }_{i, t}+\beta_{3} \text { Size }_{i, t}+\beta_{4} B t \text { Btm }_{i, t}} \\
& +\beta_{5} F c f_{i, t}+\beta_{6} \ln (\text { Idiosyn })_{i, t}+\beta_{7} \text { Tenure }_{i, t}+\beta_{8} \ln \left(B d \_s i z e\right)_{i, t} \\
& +\beta_{9} \ln (\text { Num_mtg })_{i, t}+\beta_{10} \text { Dual }_{i, t}+\beta_{11} \text { Comp_ind }_{i, t} \\
& +\sum_{j=1}^{4} \beta_{j+11} \text { Year }+\sum_{j=1}^{13} \beta_{j+15} \text { Industry }+\varepsilon_{i, t} \\
& (t=1998-2002)
\end{aligned}
$$

Where: Inst_Hor represents Short and Long.

See table 1 for variable measurement. Unlike Option_PPS, which only considers the sensitivity of new option grants to stock price, Equity_incen captures the pay-for-performance sensitivity from CEO equity portfolio incentives. A negative association between the holdings by long-term institutions and the level of total CEO portfolio of equity (Equity_incen) will be consistent with my 
prediction. ${ }^{14)}$

Table 5 reports the estimation results for equation 4 . In relation to measurement of $\mathrm{CEO}$ portfolio incentive, column 1 reports the results when Core and Guay (1999)'s a percentage-change measure is used, whereas column 2 reports the results when Jensen and Murphy (1990)'s dollar-change measure is used. Consistent with prior research, CEO equity incentives are positively correlated with noisier operating environment and with tenure, but negatively correlated with book-to-market ratio (Core and Guay, 1999). As Core and Guay (1999) demonstrate, firm size is positively correlated with a percentage change incentive measure but negatively correlated with a dollar-change incentive measure.

Consistent with my prediction, column 1 indicates that the percentage holdings by long-term investors (Long) are significantly negatively correlated with the pay-for-performance sensitivity from $\mathrm{CEO}$ equity portfolio ( $\mathrm{t}-\mathrm{statistic}=-4.76$, two-tailed). As expected, the percentage holdings by short-term investors (Short) are not related to the pay-for-performance sensitivity from CEO equity portfolio (t-statistic $=0.93$, two-tailed). Using an alternative measure of CEO equity incentive does not alter the results as seen in column 2. Long continues to be significantly negative (t-statistic $=-4.56$, two-tailed) and Short continues to be insignificant (t-statistic $=0.42$, two-tailed).

These findings, combined with the results in the previous section, suggest that short-term institutions can create incentives for the board to structure CEO pay mix toward stock options with higher sensitivity to stock price but that short-term investment horizons create little incentive to influence the sensitivity of CEO wealth to stock price. Taken together, the results suggest that long-term institutions make direct monitoring of effort more costeffective than employing compensation contracts that impose greater risk on CEOs-a risk that, in turn, leads to higher executive compensation. ${ }^{15}$

14) I provide no prediction for the association between the holdings by short-term institutions and Equity_incen because short-term institutions have little incentive to affect CEO portfolio incentives.

15) This result stands in contrast to prior research suggesting a complementary relation between concentrated institutional monitoring and the degree of pay-forperformance documented by prior research (Hartzell and Starks, 2003; Almazan, Hartzell, and Starks, 2005). As discussed in this section, a complementary relation between monitoring and incentives documented by Hartzell and Starks (2003) and Almazan, Hartzell, and Starks (2005) disappears once a proper size 
Table 5. Influence of Institutional Investment Horizons on CEO Equity Portfolio Incentives

Equity_incen $_{i, t}=\beta+\beta_{1}$ Concen_Top $_{i, t}+\beta_{2}$ Inst_Hor $_{i, t}+\beta_{3}$ Size $_{i, t}+\beta_{4}$ Btm $_{i, t}+\beta_{5} F c f_{i, t}$ $+\beta_{6} \ln (\text { Idiosyn })_{i, t}+\beta_{7}$ Tenure $_{i, t}+\beta_{8} \ln (\text { Bd_size })_{i, t}+\beta_{9} \ln (\text { Num_mtg })_{i, t}$ $+\beta_{10}$ Dual $_{i, t}+\beta_{11}$ Comp_ind $_{i, t}+\sum_{j=1}^{4} \beta_{j+11}$ Year $+\sum_{j=1}^{13} \beta_{j+15}$ Industry $+\varepsilon_{i, t}$ $(\mathrm{t}=1998-2002)$

\begin{tabular}{|c|c|c|c|}
\hline \multirow{3}{*}{ Variable } & \multirow{3}{*}{$\begin{array}{c}\text { Predicted } \\
\text { sign }\end{array}$} & $(1)$ & (2) \\
\hline & & $\begin{array}{l}\text { Core and Guay (1999) } \\
\text { incentive measure }\end{array}$ & $\begin{array}{c}\text { Jensen and Murphy (1990) } \\
\text { incentive measure }\end{array}$ \\
\hline & & Coefficient (t-statistic) & Coefficient (t-statistic) \\
\hline Constant & & $\begin{array}{l}3.547 * * * \\
(6.89)\end{array}$ & $\begin{array}{l}8.191 * * * \\
(15.43)\end{array}$ \\
\hline Concen_Top5 & ? & $\begin{array}{l}0.411 \\
(1.44)\end{array}$ & $\begin{array}{l}0.519 * \\
(1.74)\end{array}$ \\
\hline Short & ? & $\begin{array}{l}0.196 \\
(0.93)\end{array}$ & $\begin{array}{l}0.180 \\
(0.42)\end{array}$ \\
\hline Long & - & $\begin{array}{l}-1.058 * * * \\
(-4.76)\end{array}$ & $\begin{array}{l}-1.094 * * * \\
(-4.56)\end{array}$ \\
\hline Size & + & $\begin{array}{l}0.699 * * * \\
(26.80)\end{array}$ & $\begin{array}{l}-0.291 * * * \\
(-9.87)\end{array}$ \\
\hline Btm & - & $\begin{array}{l}-0.443 * * * \\
(-5.84)\end{array}$ & $\begin{array}{l}-0.480 * * * \\
(-5.73)\end{array}$ \\
\hline$F c f$ & - & $\begin{array}{l}0.019 \\
(0.18)\end{array}$ & $\begin{array}{l}0.012 \\
(0.11)\end{array}$ \\
\hline Idiosyn & + & $\begin{array}{l}0.244 * * * \\
(2.71)\end{array}$ & $\begin{array}{l}0.275^{* * *} \\
(2.92)\end{array}$ \\
\hline Tenure & + & $\begin{array}{l}0.063 * * * \\
(14.69)\end{array}$ & $\begin{array}{l}0.063 * * * \\
(13.45)\end{array}$ \\
\hline Bd_size & ? & $\begin{array}{l}-0.585 * * * \\
(-4.59)\end{array}$ & $\begin{array}{l}-0.585^{* * *} \\
(-4.26)\end{array}$ \\
\hline Num_mtg & ? & $\begin{array}{l}-0.220 * * * \\
(-2.76)\end{array}$ & $\begin{array}{l}-0.240 * * * \\
(-2.79)\end{array}$ \\
\hline Dual & ? & $\begin{array}{l}0.218 * * * \\
(4.34)\end{array}$ & $\begin{array}{l}0.234 * * * \\
(4.43)\end{array}$ \\
\hline Comp_ind & $?$ & $\begin{array}{l}-0.304 * * \\
(-2.18)\end{array}$ & $\begin{array}{l}-0.277 * \\
(-1.87)\end{array}$ \\
\hline $\begin{array}{r}N \\
\text { Adjusted } R-s\end{array}$ & squared & $\begin{array}{r}4031 \\
63.3 \%\end{array}$ & $\begin{array}{r}4031 \\
43.4 \%\end{array}$ \\
\hline
\end{tabular}

$*{ }^{* *}$, and ${ }^{* * *}$ : Significant at the $10 \%, 5 \%$ and $1 \%$ levels, respectively (two-tailed). For parsimony, the coefficients on year-dummies and industry dummies are not reported. See table 1 for variable definitions.

OLS standard errors are based on Rogers (1993) serial correlation and heteroskedasticity robust standard errors. 


\section{Effect of Institutional Investment Horizons on the Adverse Effect of Negative Earnings Surprise on CEO Annual Bonus}

To test my prediction, I estimate the following regression equations, building on Matsunaga and Park (2001).

$$
\begin{aligned}
& \Delta \text { Bonus }_{i, t}=\beta+\beta_{1} \text { Short }_{i, t}+\beta_{2} \text { Long }_{i, t}+\beta_{3} \text { Negfe }_{i, t}+\beta_{4} \text { Negfe }_{i, t} \\
& +\beta_{5} \text { Negfe }_{i, t}+\beta_{6} \text { Negfe }_{i, t}+\beta_{7} \text { Short }_{i, t}{ }^{*} \text { Negfe }_{i, t}+ \\
& \beta_{8} \text { Shor }_{i, t^{*}} \text { Negfe }_{i, t^{*}}+\beta_{9} \text { Short }_{i, t^{*}} \text { Negfe }_{i, t}+\beta_{10} \text { Short }_{i,{ }^{*}} \text { Negfe }_{i, t} \\
& +\beta_{11} \text { Long }_{i, t^{*}} \text { Negfe }_{i, t}+\beta_{12} \text { Long }_{i, t^{*}} \text { Negfe }_{i, t} \\
& +\beta_{13} \text { Long }_{i, t} \text { Negfe }_{i, t}+\beta_{14} \text { Long }_{i, t} \text { Negfe }_{i, t}+\beta_{15} \Delta \text { Earn }_{i, t} \\
& +\beta_{16} \operatorname{Ret}_{i, t}+\varepsilon_{i, t}
\end{aligned}
$$

$$
\begin{aligned}
& \Delta \text { Bonus }_{i, t}=\beta+\beta_{1} \text { Short }_{i, t}+\beta_{2} \text { Long }_{i, t}+\beta_{3} \text { Decrease }_{i, t}+\beta_{4} \text { Decrease }_{i, t} \\
& +\beta_{5} \text { Decrease }_{i, t}+\beta_{6} \text { Decrease }_{i, t}+\beta_{7} \text { Short }_{\mathrm{i}, \mathrm{t}} \text { Decrease } 1_{\mathrm{i}, \mathrm{t}} \\
& +\beta_{8} \text { Short }_{i, t^{*}} \text { Decrease }{ }_{i, t}+\beta_{9} \text { Short }_{i, t^{*}} \text { Decrease } 3_{i, t} \\
& +\beta_{10} \text { Short }_{i, t^{*}} \text { Decrease }_{i, t}+\beta_{11} \text { Long }_{i, t^{*}} \text { Decrease }_{i, t} \\
& +\beta_{12} \text { Long }_{i, t} \text { Decrease } 2_{i, t}+\beta_{13} \text { Long }_{i, t} \text { Decrease }{ }_{i, t} \\
& +\beta_{14} \text { Long }_{i, t^{*}} \text { Decrease }_{i, t}+\beta_{15} \Delta \text { Earn }_{i, t}+\beta_{16} \text { Ret }_{i, t}+\varepsilon_{i, t}
\end{aligned}
$$

See table 1 for other variable measurements. Following Matsunaga and Park (2001), I control for the general pay-performance relation by including both accounting performance and market performance (Lambert and Lacker 1987; Sloan 1993) and use separate indicator variables for the year's number of quarters that the firm missed the earnings benchmark.

I predict that the adverse effect that a firm's missing an earnings benchmark has on the firm's CEO compensation will be positively associated with the percentage of shares held by short-term institutional investors. Therefore, I expect the coefficients on the interaction terms between the holdings by institutions with a short horizon and the indicator variables corresponding to the number of quarterly negative earnings surprises $\left(\beta_{7}, \beta_{8}, \beta_{9}\right.$, and $\beta_{10}$ in equations (5) and (6)) to be significantly negative. However, I expect the coefficients on the interaction terms between the long-term holdings and the indicator variables corresponding to the number of quarterly negative earnings surprises to be insignificant. 
Table 6 reports how institutional investment horizons influence the CEO's bonus after a firm misses an earnings benchmark. Column 1 reports the results when a consensus analyst earnings forecast is used as an earnings benchmark, whereas column 2 reports the results when earning for the same quarter of the prior year is used as an earnings benchmark. ${ }^{16)}$

The coefficients on the interaction term between each dummy variable capturing the number of quarters of reporting negative earnings surprise and the percentage of institutional holdings held by short-term institutions (Short) enable me to examine the effect that investment horizon heterogeneity has on CEO bonus penalties. Columns 1 and 2 indicate that with the exception of the coefficients on Short*Decrease1, Short*Decrease2, all the coefficients on Short*Negfe and Short*Decrease are significantly negative ( $\mathrm{p}<0.05$ or less, two-tailed). Consistent with my prediction, the boards belonging to firms with a higher percentage of shortterm institutional ownership are more concerned about a negative earnings surprise and punish their CEOs more severely.

In contrast, the coefficients on the interaction term between the number of quarters of reporting negative earnings surprise and long-term institutional ownership (Long) are not statistically significant except for the negative coefficients on Long*Negfe 4 and Long*Decrease 4 . Note that these findings hold whether consensus analyst forecast or earning for the same quarter of the prior year is used as an earnings benchmark. ${ }^{17)}$

Combined, the results provide strong support for the contention that investment behavior of institutions plays an important role in influencing a board's perception of the costs of missing an earnings benchmark. My findings also lend support to Matsumoto's (2002) contention that higher short-term institutional ownership provides managers with strong incentives to meet or exceed earnings benchmarks, in part, because CEOs in firms with higher shortterm ownership face reduced annual bonuses if the firms miss a quarterly earnings benchmark.

16) Another earnings benchmark that could be considered is zero earnings. Matsunaga and Park (2001), however, do not find evidence that CEOs are penalized when they report negative quarterly earnings.

17) To arrive at an alternative measure, I measure the dependent variable that features a change in the natural log of CEO salary plus bonus (Lambert and Larcker, 1987; Sloan, 1993) and repeat the analyses. The results are similar. 
Table 6. Influence of Institutional Investment Horizons on the Adverse Effect of Negative Earnings Surprise on CEO Annual Bonus

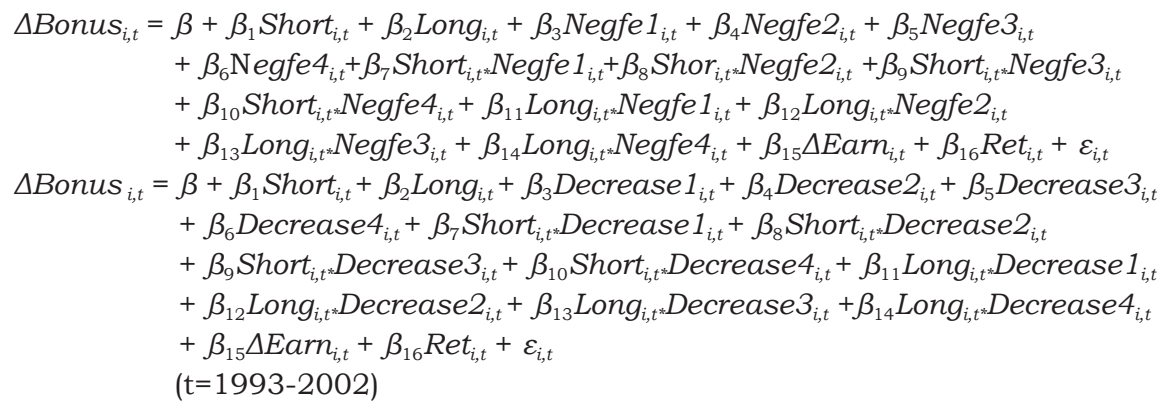

\begin{tabular}{|c|c|c|c|c|c|}
\hline \multirow{4}{*}{ Variable } & \multirow{4}{*}{ Predicted Sign } & \multicolumn{4}{|c|}{ Earnings Benchmark } \\
\hline & & \multirow{2}{*}{\multicolumn{2}{|c|}{$\begin{array}{c}\text { Analyst Forecast } \\
\text { (1) }\end{array}$}} & \multicolumn{2}{|c|}{ Prior Year } \\
\hline & & & & \multicolumn{2}{|c|}{ (2) } \\
\hline & & \multicolumn{4}{|c|}{ Coefficient (t-statistic) } \\
\hline Constant & ? & $\begin{array}{l}0.096 \\
(1.92)\end{array}$ & * & $\begin{array}{l}0.079 \\
(1.87)\end{array}$ & * \\
\hline Short & ? & $\begin{array}{l}0.137 \\
(1.41)\end{array}$ & & $\begin{array}{l}0.337 \\
(3.73)\end{array}$ & $* * *$ \\
\hline Long & $?$ & $\begin{array}{l}0.147 \\
(1.49)\end{array}$ & & $\begin{array}{l}0.148 \\
(1.73)\end{array}$ & * \\
\hline Negfe 1 & - & $\begin{array}{l}-0.101 \\
(-1.40)\end{array}$ & & & \\
\hline Negfe2 & - & $\begin{array}{l}-0.134 \\
(-1.76)\end{array}$ & * & & \\
\hline Negfe3 & - & $\begin{array}{l}-0.164 \\
(-1.83)\end{array}$ & * & & \\
\hline Negfe4 & - & $\begin{array}{l}-0.006 \\
(-0.05)\end{array}$ & & & \\
\hline Decrease 1 & - & & & $\begin{array}{l}-0.136 \\
(-1.82)\end{array}$ & * \\
\hline Decrease2 & - & & & $\begin{array}{l}-0.278 \\
(-3.50)\end{array}$ & $* * *$ \\
\hline Decrease3 & - & & & $\begin{array}{l}-0.142 \\
(-1.60)\end{array}$ & \\
\hline Decrease4 & - & & & $\begin{array}{l}0.109 \\
(1.08)\end{array}$ & \\
\hline Short*Negfe 1 & - & $\begin{array}{l}-0.459 \\
(-3.04)\end{array}$ & $* * *$ & & \\
\hline
\end{tabular}


Table 6. (Continued)

\begin{tabular}{|c|c|c|c|}
\hline \multirow{2}{*}{ Variable } & \multirow{2}{*}{ Predicted Sign } & Analyst Forecast & Prior Year \\
\hline & & \multicolumn{2}{|c|}{ Coefficient(t-statistic) } \\
\hline Short*Negfe2 & - & $\begin{array}{l}-0.602^{* * *} \\
(-3.44)\end{array}$ & \\
\hline Short*Negfe3 & - & $\begin{array}{l}-0.508^{* *} \\
(-2.21)\end{array}$ & \\
\hline Short*Negfe 4 & - & $\begin{array}{l}-0.715^{* *} \\
(-2.17)\end{array}$ & \\
\hline Short*Decrease 1 & - & & $\begin{array}{l}-0.083 \\
(-0.49)\end{array}$ \\
\hline Short*Decrease 2 & - & & $\begin{array}{l}-0.233 \\
(-1.30)\end{array}$ \\
\hline Short*Decrease 3 & - & & $\begin{array}{l}-0.828^{* * *} \\
(-4.30)\end{array}$ \\
\hline Short*Decrease 4 & - & & $\begin{array}{l}-1.302^{* * *} \\
(-6.37)\end{array}$ \\
\hline Long ${ }^{*}$ Negfe 1 & ? & $\begin{array}{l}0.094 \\
(0.65)\end{array}$ & \\
\hline Long*Negfe2 & ? & $\begin{array}{l}-0.049 \\
(-0.31)\end{array}$ & \\
\hline Long ${ }^{*}$ Negfe 3 & ? & $\begin{array}{l}-0.106 \\
(-0.57)\end{array}$ & \\
\hline Long*Negfe4 & ? & $\begin{array}{l}-0.518^{*} \\
(-1.83)\end{array}$ & \\
\hline Long*Decrease 1 & ? & & $\begin{array}{l}0.037 \\
(0.24)\end{array}$ \\
\hline Long*Decrease2 & ? & & $\begin{array}{l}0.067 \\
(0.41)\end{array}$ \\
\hline Long ${ }^{*}$ Decrease 3 & ? & & $\begin{array}{l}-0.150 \\
(-0.82)\end{array}$ \\
\hline Long*Decrease 4 & ? & & $\begin{array}{l}-0.669 * * * \\
(-3.30)\end{array}$ \\
\hline$\Delta$ Earn & + & $\begin{array}{l}1.980^{* * *} \\
(18.25)\end{array}$ & $\begin{array}{l}1.611^{* * *} \\
(14.13)\end{array}$ \\
\hline Ret & + & $\begin{array}{l}0.226^{* * *} \\
(13.50)\end{array}$ & $\begin{array}{l}0.194^{* * *} \\
(11.48)\end{array}$ \\
\hline$N$ & & 9433 & 9433 \\
\hline Adjusted R-squared & & $11.1 \%$ & $12.4 \%$ \\
\hline
\end{tabular}

See table 1 for variable definitions. ${ }^{*},{ }^{* *}$, and ${ }^{* * *}$ : Significant at the $10 \%, 5 \%$ and $1 \%$ levels, respectively (two-tailed).

OLS standard errors are based on Rogers (1993) serial correlation and heteroskedasticity robust standard errors. 


\section{Robustness Checks}

\section{Case of 'Star' CEOs.}

There has been an unprecedented quest for superstar CEOs in the managerial-labor market (Murphy and Zabojnik1 2003). To the extent that superstar CEOs are in higher demand in the labor market, firms will have less negotiating power to structure CEO compensation according to investors' preferences. In contrast, theory predicts that the structure of optimal contracting does not vary with the relative bargaining powers of the related parties (Bolton, Scheinkman, and Xiong 2005).

Using CEO press-citation data (e.g., number of major US news articles containing a CEO's name) from Rajgopal, Shevlin, and Zamora (2006), ${ }^{18)}$ I created a sub-sample of firms whose CEOs fall into the top quartile in terms of "visibility" in the financial press as a proxy for CEO talent. I repeat all previous analyses for this subsample. Consistent with theoretical studies in optimal contracting, all of the previous findings are unchanged.

\section{Alternative Measure of Investment Horizons.}

Gaspar, Massa, and Matos (2005) propose a measure of investor turnover, the measure of how frequently each institution rotates its position on all the stocks of its portfolio (churn rate) to capture the length of investment horizons (see Gaspar, Massa, and Matos 2005 for a detailed calculation of their investor-turnover measure). Because institutional investment horizons are naturally hard to observe, I repeat all previous analyses by using an investor-turnover measure that derives from Gaspar, Massa, and Matos (2005) in place of Short and Long..$^{19)}$ All of the previous findings are unchanged and robust to an alternative measure of institutional investment horizons.

18) Rajgopal, Shevlin, and Zamora (2006) use the number of articles containing a CEO's name that appear in the major US and global business newspapers as a proxy for CEO talent for S\&P 500 firms from 1993 to 2001.

19) As expected, an investor-turnover measure is positively correlated with the percentage holdings by short-term institutions (the correlation is 0.42 ) and negatively correlated with the percentage holdings by long-term institutions (the correlation is -0.21). 


\section{Controlling for Legal Form of Institutions.}

Prior research suggests that the extent to which institutions are willing to monitor managers is different across legal form of institutions (Almazan, Hartzel, and Starks 2005; Brickley, Lease, and Smith 1988). Thus, I repeat all previous analyses after additionally controlling for the percentage holdings by banks, insurance companies, investment advisors, and pension and endowment. All of the previous findings are unchanged and robust to adding legal form of institutions as a control.

\section{CONCLUSION}

In this paper, I examine whether the investment horizons of a firm's institutional investors are associated with the structure of CEO compensation. I argue and predict that the investment horizon of institutional investors can both directly and indirectly influence executive compensation.

I find that short-term institutions could encourage the board of directors to structure executive compensation practices on the basis of short-term investors' preferences (e.g., more stock options that do not need to be expensed, higher option sensitivity to stock price, and larger annual bonus penalties for missing quarterly earnings benchmarks). Short-term institutions, however, do not appear to influence CEO equity holdings incentives. On the other hand, and in line with an optimal contracting view of CEO compensation, I find that long-term institutional monitoring is likely a substitute for managerial incentives.

Overall, the analyses provide evidence consistent with the influence that shareholder investment horizons have on the structure of $\mathrm{CEO}$ compensation. By explicitly relating institutional investment horizons to executive compensation, my study adds to the growing literature that links managerial compensation to shareholder investor horizons (Bolton, Scheinkman, and Xiong 2005, 2006; Dikolli, Kulp, and Sedatole 2006) and to the literature on the governance role of institutional trading (Gopalan 2005). This study should be of interest to regulators, investors, and boards of directors, all of which may need to manage a firm's investor base and to mitigate undue influences from investor clientele. 


\section{APPENDIX}

\section{Estimation of Simultaneous Equations}

Given the potential for endogeneity between firms' use of stock options and institutional holdings by investment horizons, I estimate the following system of two equations in an effort to understand the nature of the observed relation:

$$
\begin{aligned}
& \% \text { Equity_grant }_{i, t}=\beta+\beta_{1} \text { Inst_Hor }_{i, t}+\beta_{2} \text { Noise_roa }_{i, t}+\beta_{3} \text { Noise_ret }_{i, t} \\
& +\beta_{4} \text { High_tax }_{i, t}+\beta_{5} \text { Low }_{-} \operatorname{tax}_{i, t}+\beta_{6} \operatorname{Lev}_{i, t}+\beta_{7} \text { Btm }_{i, t} \\
& +\beta_{8} \text { Ownership }{ }_{i, t}+\beta_{9} \text { Size }_{i, t}+\beta_{10} \text { New }_{i, t}+\beta_{11} F c f_{i, t} \\
& +\beta_{12} \text { Bd_size } \text { it, }_{1}+\beta_{13} N u m \_ \text {mtg }{ }_{i, t}+\beta_{14} \text { Dual }_{i, t} \\
& +\beta_{15} \text { Bd_ind } \text { int }+\beta_{16} \text { Tenure }_{i, t}+\beta_{17} \text { Dirown }_{i, t} \\
& +\sum_{j=1}^{4} \beta_{j+17} \text { Year }+\sum_{j=1}^{13} \beta_{j+21} \text { Industry }+v_{1, t} \\
& (t=1998-2002)
\end{aligned}
$$

$$
\begin{aligned}
& \text { Inst_Hor }_{i, t}=\beta+\beta_{1} \% \text { Equity_grant }_{i, t}+\beta_{2} \text { SP } 50 O_{i, t}+\beta_{3} \text { Btm }_{i, t}+\beta_{4} \text { Size }_{i, t} \\
& +\beta_{5} \text { Beta }_{i, t}+\beta_{6} \text { Idiosyn }_{i, t}+\beta_{7} \text { Lev }_{i, t}+\beta_{8} \text { Loss }_{i, t}+\beta_{9} \text { SPrating }_{i, t} \\
& +\beta_{10} M-\text { ret }_{i, t}+\beta_{11} D p_{i, t}+\beta_{12} E p_{i, t}+\beta_{13} C f o_{i, t}+\beta_{14} L i q_{i, t} \\
& +\beta_{15} \text { Sgr }_{i, t}+\sum_{j=1}^{4} \beta_{j+15} \text { Year }+\sum_{j=1}^{13} \beta_{j+19} \text { Industry }+u_{2, t} \\
& (t=1998-2002)
\end{aligned}
$$

$S P 500=1$ if the firm is part of the S\&P 500, and 0 otherwise

Beta $=$ the market model beta, estimated over a maximum 60 and minimum of 12 months

Idiosyn $=$ unsystematic risk, defined as the standard deviation of daily market model residuals over the prior year

Loss $=1$ if the firm reports a net loss, and 0 otherwise

SPrating $=$ S\&P common stock rating

$M \_r e t=$ the market adjusted return

$D p=$ dividend-to-price ratio

$E p=$ earnings-price-ratio

$C f o=$ cash flow from operations

Liq $=$ average monthly trading volume divided by shares 


\author{
outstanding over the year \\ $S g r=$ sales growth relative to previous year
}

I first regress each endogenous variable on all exogenous variables. In the second stage, equations (8) and (9) are separately estimated with the right-side endogenous variable replaced by its fitted value from the first stage regression.

\title{
REFERENCES
}

Aboody, D. and R. Kasznik (2000), "CEO Stock Option Awards and the Timing of Corporate Voluntary Disclosures," Journal of Accounting and Economics, 29, 73-100.

Aboody, D., M. Barth, and R. Kasznik (2004), "Firms' Voluntary Recognition of Stock-Based Compensation Expense," Journal of Accounting Research, 42, 123-150.

Almazan, A., J. Hartzell, and L. Starks (2005), "Active Institutional Shareholders and Cost of Monitoring: Evidence from Executive Compensation," Financial Management, 34, 5-34.

Baber, W., S. Janakiraman, S. Kang (1996), "Investment Opportunities and the Structure of Executive Compensation," Journal of Accounting and Economics, 21, 297-318.

Barth, M., J. Elliott, and M. Finn (1999), "Market Rewards Associated with Patterns of Increasing Earnings," Journal of Accounting Research, 37, 387-413.

Bartov, E., D. Givoly, and C. Hayn (2002), "The Reward to Meeting or Beating Earnings Expectations," Journal of Accounting and Economics, 33, 173-204.

Bergstresser, D. and T. Philippon (2006), "CEO Incentives and Earnings Management: Evidence from the 1990s," Journal of Financial Economics, 80, 511-529.

Bolton, P., J. Scheinkman, and W. Xiong (2005), "Pay for Short-Term Performance: Executive Compensation in Speculative Markets," Journal of Corporation Law, 30, 712-745.

(2006), "Executive Compensation and Short-Termist Behavior in Speculative Markets," Review of Economic Studies, 73, 577-610.

Botosan, C. and M. Plumlee (2001), "Stock Options Expense: The Sword of Damocles Revealed," Accounting Horizons, 15, 311-327.

Brandes, P., M. Hadani, and M. Goranova (2006), "Stock Options Expensing: An Examination of Agency and Institutional Theory Explanations," Journal of Business Research, 59, 595-603. 
Brickley, J., R. Lease, and C. Smith (1988), "Ownership Structure and Voting on Antitakeover Amendments," Journal of Financial Economics, 20. 267-291.

Bryan, S., L. Hwang, and S. Lilien (2000), "CEO Stock-Based Compensation: An Empirical Analysis of Incentive Intensity, Relative Mix, and Economic Determinants," Journal of Business, 73, 661-694.

Burns, N. and S. Kedia (2006), "The Impact of Performance-Based Compensation on Misreporting," Journal of Financial Economics, 79, 35-67.

Burns, N., S. Kedia, and M. Lipson (2006), "The Effects of Institutional Ownership and Monitoring: Evidence from Financial Restatements," Working paper, Rutgers University.

Bushee, B. (1998), "The Influence of Institutional Investors on Myopic R\&D Investment Behavior," The Accounting Review, 73, 305-333. (2001), "Do Institutional Investors Prefer Near-Term Earnings Over Long-Run Value?” Contemporary Accounting Research, 18, 207-246. (2004), "Identifying and Attracting the "Right" Investors: Evidence on the Behavior of Institutional Investors," Journal of Applied Corporate Finance, 16, 28-35.

Bushee, B. and C. Noe (2000), "Corporate Disclosure Practices, Institutional Investors, and Stock Returns Volatility," Journal of Accounting Research, 38, 171-202.

Carter, E. and L. Lynch (2003), “The Consequences of the FASB's 1998 Proposal on Accounting for Stock Option Repricing," Journal Accounting and Economics, 35, 51-72.

Carter, E., L. Lynch, and I. Tuna (2007), "The Role of Accounting in the Design of CEO Equity Compensation," The Accounting Review, 82, 327358.

Chan, L. and J. Lakonishok (1995), "The Behavior of Stock Prices Around Institutional Trades," Journal of Finance, 50, 1147-1174.

Chen, X., J. Hartford, and K. Li (2007), "Monitoring: Which Institutions Matter?” Journal of Financial Economics, 86, 279-305.

Cheng, Q. and T. Warfield (2005), "Equity Incentives and Earnings Management," The Accounting Review, 80, 441-476.

Cho, S., (2009), "The Effect of Target Ownership Structure in the Wealth Gains in Owner-Manager Dominant Acquisitions: Evidence from Korean Cases," Seoul Journal of Business, 15(1), 39-64.

Choi, J., S. Kwak, and H. Yoo (2007), "The Association between Audit Fees and the Ownership Structure," Seoul Journal of Business, 13(2), 83103.

(2008), "The Effect of Divergence between Cash Flow Right and Voting Right on Audit Hour and Audit Fee per Audit Hour," Seoul Journal of Business, 14(1), 55-77.

Coles, J., N. Daniel, and L. Naveen (2006), "Managerial Incentives and Risk- 
Taking," Journal of Financial Economics, 79, 431-468.

Core, J. and W. Guay (1999), "The Use of Equity Grants to Manage Optimal Equity Incentive Levels," Journal of Accounting and Economics, 28, 151184.

Cornett, M., A. Marcus, and H. Tehranian (2007), "Corporate Governance and Pay-for-Performance: The Impact of Earnings Management," Journal of Financial Economics, Forthcoming.

Davis, G. and E. H. Kim (2007), "Business Ties and Proxy Voting by Mutual Funds," Journal of Financial Economics, 85, 552-570.

Del Guercio, D. and J. Hawkins (1999), "The Motivation and Impact of Pension Fund Activism," Journal of Financial Economics, 52, 293-340.

Dikolli, S., S. Kulp, and K. Sedatole (2006), "Transient Institutional Ownership and CEO Contracting," Working paper, University of Texas at Austin.

Effendi, J., A. Srivastava, and E. Swanson (2007), "Why Do Managers Misstate Financial Statements? The Role of Option Compensation and Other Factors," Journal of Financial Economics, 85, 667-708.

Engel, E., E. Gordon, and R. Hayes (2002), "The Roles of Performance Measures and Monitoring in Annual Governance Decisions in Entrepreneurial Firms," Journal of Accounting Research, 40, 485-518.

Espahbodi, H., P. Espahbodi, Z. Rezaee, and H. Tehranian (2002), "Stock Price Reaction and Value-Relevance of Recognition versus Disclosure: The Case of Stock-Based Compensation," Journal of Accounting and Economics, 33, 343-373.

Ferri, F., T. Sandino, and G. Markarian (2006), "The Role of Shareholder Activism in Governance Reform: The Case of Stock Options Expensing," Working paper, Harvard University.

Gaspar, J., M. Massa, and P. Matos (2005), "Shareholder Investment Horizons and the Market for Corporate Control," Journal of Financial Economics, 76, 135-165.

Gillan, S. and L. Starks (2000), "Corporate Governance Proposals and Shareholder Activism: The Role of Institutional Investors," Journal of Financial Economics, 57, 275-305.

(2003), "Corporate Governance, Corporate Ownership, and the Role of Institutional Investors: A Global Perspective," Journal of Applied Finance, 13, 4-22.

Gopalan, R. (2005), "Large Shareholder Trading and Takeovers: The Disciplinary Role of Voting with Your Feet," Working paper, University of Michigan.

Graham, J., C. Harvey, and S. Rajgopal (2005), "The Economic Implications of Corporate Financial Reporting," Journal of Accounting and Economics, 40, 3-73.

Grossman, S. and O. Hart (1980), "Takeover Bids, the Free Rider Problem, 
and the Theory of the Corporation," Bell Journal of Economics, 11, 4264.

Hanlon, M., S. Rajgopal, and T. Shevlin (2003), "Are Stock Options Associated with Future Earnings?" Journal of Accounting and Economics, 36, 3-43.

Hartzell, J. and L. Starks (2003), "Institutional Investors and Executive Compensation," Journal of Finance, 58, 2351-2374.

Heron, R. and E. Lie (2007), "Does Backdating Explain the Stock Price Pattern Around Executive Stock Option Grants?” Journal of Financial Economics, 83, 271-295.

Himmelberg, C., G. Hubbard, and D. Palia (1999), "Understanding the Determinants of Managerial Ownership and the Link Between Ownership and Performance," Journal of Financial Economics, 53, 353384.

Holmstrom, B. and S. Kaplan (2001), "Corporate Governance and Merger Activity in the United States: Making Sense of the 1980s and 1990s," Journal of Economic Perspectives, 15, 121-144.

Hotchkiss, E. and D. Strickland (2003), "Does Shareholder Composition Matter? Evidence from the Market Reaction to Corporate Earnings Announcements," Journal of Finance, 58, 1469-1498.

Hu, X. (2006), "Do Mutual Fund Put Their Money Where Their Mouth Is? The Case of Expensing Stock Options," Working paper, University of Southern California.

Ittner, C., D. Larcker, and R. Lambert (2003), "The Structure and Performance Consequences of Equity Grants to Employees of New Economy Firms," Journal of Accounting and Economics, 34, 89-127.

Jensen, M. and K. Murphy (1990), "Performance Pay and Top Management Incentives," Journal of Political Economy, 98, 225-264.

Kasznik, R. and M. McNichols (2002), "Does Meeting Earnings Expectations Matter? Evidence from Analyst Forecast Revisions and Share Prices," Journal of Accounting Research, 40, 727-759.

Ke, B., K. Petroni, and A. Safieddine (1999), "Ownership Concentration and Sensitivity of Executive Pay to Accounting Performance: Evidence from Publicly and Privately-Held Insurance Companies," Journal of Accounting and Economics, 28, 185-209.

Kimbrough, M. and H. Louis (2004), "Financial Reporting Incentives, Managerial Influence, and the Trade-Off Among Alternative Forms of Executive Compensation," Working paper, Harvard University.

Lambert, R. and D. Larcker (1987), "An Analysis of the Use of Accounting and Market Measures of Performance on Executive Compensation Contracts," Journal of Accounting Research, 25, 95-125.

Lie, E. (2005), "On the Timing of CEO Stock Option Awards," Management Science, 51, 802-812. 
Matsumoto, D. (2002), "Management Incentive to Avoid Negative Earnings Surprises," The Accounting Review, 77, 483-514.

Matsunaga, S. (1995), "The Effect of Financial Reporting Costs on the Use of Employee Stock Options," The Accounting Review, 70, 1-26.

Matsunaga, S. and C. Park (2001), "The Effect of Missing a Quarterly Earnings Benchmark on the CEO's Annual Bonus," The Accounting Review, 76, 313-332.

McConnell, P., J. Pegg, D. Mott, and C. Senyek (2004), FASB does it: FAS $123(R)$ requires stock option expensing, Bear Stearns Equity Research (December 16).

(2005), 2004 Earnings impact of stock options on the S\&P $500 \&$ NASDAQ 100 earnings, Bear Stearns Equity Research (March 21).

Mehran, H. (1995), "Executive Compensation Structure, Ownership, and Firm Performance," Journal of Financial Economics, 38, 163-184.

Murphy, K. (2003), "Stock-Based Pay in New Economy Firms," Journal of Accounting and Economics, 34, 129-147.

Murphy, K. and J. Zabojnik (2003), "Managerial Capital and the Market for CEOs," Working Paper, University of Southern California.

Parrino, R., R. Sias, and L. Starks (2003), "Voting with Their Feet: Institutional Ownership Changes Around Forced CEO Turnover," Journal of Financial Economics, 68, 3-46.

Rajgopal, S., L. Shivakumar, and A. Simpson (2007), "A Catering Theory of Earnings Management," Working paper, University of Washington at Seattle.

Rajgopal, S., T. Shevlin, and T. Zamora (2006), “CEOs' Outside Employment Opportunities and the Lack of Relative Performance Evaluation in Compensation Contracts," Journal of Finance, 61, 1813-1844.

Rogers, W. (1993), "Regression Standard Errors in Clustered Samples," in Stata Technical Bulletin Reprints, vol. 3, Stats Press, College Station, TX: 83-94.

Rothberg, B. and S. Lilien (2005), "Mutual Fund Proxy Votes," Working paper, City University of New York at Baruch.

Shleifer, A. and R. Vishny (1986), "Large Shareholders and Corporate Control," Journal of Political Economy, 94, 461-488.

Sloan, R. (1993), "Accounting Earnings and Top Executive Compensation," Journal of Accounting and Economics, 16, 55-100.

Skinner, D. and R. Sloan (2002), "Earnings Surprises, Growth Expectations and Stock Returns, or Don't Let an Earnings Torpedo Sink Your Portfolio," Review of Accounting Studies, 7, 289-312.

Smith, G. and P. Swan (2007), "Too Good to be True: Do Institutional Investors Really Monitor Executive Compensation?” Working Paper, University of New South Wales.

Smith, C. and R. Watts (1992), "The Investment Opportunity Set and 
Corporate Financing, Dividend, and Compensation Policies," Journal of Financial Economics, 32, 263-292.

Venkatachalam, M. (2000), "Discussion of Corporate Disclosure Practices, Institutional Investors, and Stock Return Volatility," Journal of Accounting Research, 38, 203-207.

Yermack, D. (1995), "Do Corporation Award CEO Stock Options Effectively?" Journal of Financial Economics, 39, 237-269.

(1997), "Good Timing: CEO Stock Option Awards and Company News Announcements," Journal of Finance, 52, 449-476.

Received February 28, 2011

Accepted April 27, 2011 
